Portland State University

PDXScholar

\title{
Recruiting Dark Personalities for Earnings Management
}

\author{
Ling L. Harris \\ University of Nebraska - Lincoln \\ Scott B. Jackson \\ University of South Carolina - Columbia \\ Joel Owens \\ Portland State University, joel.owens@pdx.edu \\ Nicholas Seybert \\ University of Maryland at College Park
}

Follow this and additional works at: https://pdxscholar.library.pdx.edu/busadmin_fac

Part of the Business Commons

Let us know how access to this document benefits you.

\section{Citation Details}

Published as: Harris, L. L., Jackson, S. B., Owens, J., \& Seybert, N. (2021). Recruiting Dark Personalities for Earnings Management. Journal of Business Ethics. https://doi.org/10.1007/s10551-021-04761-z

This Post-Print is brought to you for free and open access. It has been accepted for inclusion in Business Faculty Publications and Presentations by an authorized administrator of PDXScholar. Please contact us if we can make this document more accessible: pdxscholar@pdx.edu. 


\title{
Recruiting Dark Personalities for Earnings Management
}

\author{
Ling Harris \\ University of Nebraska-Lincoln \\ lharris6@unl.edu \\ Scott Jackson \\ University of South Carolina \\ scott.jackson@moore.sc.edu \\ Joel Owens \\ Portland State University \\ joel.owens@pdx.edu \\ Nicholas Seybert \\ University of Maryland \\ nseybert@umd.edu
}

January 25, 2021

\begin{abstract}
Acknowledgements: We are grateful to Sheila Killian (editor), three anonymous reviewers, Stephen Asare, Jeremy Bentley, Charles Boster, Joe Brazel, Michael Campion, Ben Commerford, John Core, Adrienne DePaul, Marcus Doxey, Mike Ettredge, Laura Feustel, Gary Fleischman, Brent Garza, Shawn Gordon, Emerald Harris, Rick Hatfield, Erin Hawkins, Kevin Jackson, Noah Jackson, Elena Klevsky, Ethan LaMothe, Justin Leiby, Brad Lindsey, Marlys Lipe, Tom Lopez, Michael Majerczyk, Mary Marshall, Adi Masli, Ed O'Donnell, Derek Oler, Don Pagach, Linda Parsons, Rob Ployhart, Linda Quick, Lynn Rees, Kathy Rupar, Manuel Sanchez, John Sweeney, Brad Tuttle, Nate Waddoups, Devin Williams, Yi-Jing Wu, conference participants at the 2015 AAA Annual Meeting, and workshop participants at Beijing Institute of Technology, Miami University, Nankai University, North Carolina State University, Texas Tech University, the University of Alabama, University of Florida, University of Kansas, University of Nebraska-Lincoln, University of North Texas, and the University of South Carolina for providing many insightful comments and suggestions. We also thank the business professionals who generously participated in our studies. Funding was provided by the Darla Moore School of Business Research Grant Program.
\end{abstract}




\title{
Recruiting Dark Personalities for Earnings Management
}

\author{
Abstract \\ Prior research indicates that managers' dark personality traits increase their tendency to \\ engage in disruptive and unethical organizational behaviors including accounting earnings \\ management. Other research suggests that the prevalence of dark personalities in management \\ may represent an accidental byproduct of selecting managers with accompanying desirable \\ attributes that fit the stereotype of a "strong leader." Our paper posits that organizations may hire \\ some managers who have dark personality traits because their willingness to push ethical \\ boundaries aligns with organizational objectives, particularly in the accounting context where \\ ethical considerations are especially important. Using several validation studies and experiments, \\ we find that experienced executives and recruiting professionals favor hiring a candidate with \\ dark personality traits into an accounting management position over an otherwise better-qualified \\ candidate when the hiring organization faces pressure to manage earnings. Our results help to \\ illuminate why individuals with dark personality traits may effectively compete for high-level \\ accounting positions.
}




\section{Recruiting Dark Personalities for Earnings Management}

\section{Introduction}

Prior research indicates that managers' dark personality traits increase their tendency to engage in earnings management, fraud, and a variety of other unethical or negative workplace behaviors (Duchon and Drake 2009, Amernic and Craig 2010, Boddy 2011, Kalshoven et al. 2011, Den Zona et al. 2013, Rijsenbilt and Commandeur 2013, Olsen et al. 2014, Majors 2016, Ham et al. 2017, Buchholz et al. 2019, Van Scotter and Roglio 2020). Yet, a number of other studies suggest that individuals with dark personalities may possess accompanying attributes considered desirable in a business context, such as confidence, perceived creativity, ability to manage impressions, and aggressive pursuit of business opportunities (Caldwell and O'Reilly 1982, Raskin et al. 1991, Chatterjee and Hambrick 2007, Brunell et al. 2008, Babiak et al. 2010, Goncalo et al. 2010, Nevicka et al. 2011, Zettler and Solga 2013, Ong et al. 2016). Thus, the extant literature largely frames the prevalence of dark personalities in management as an accidental byproduct of selecting managers who fit the stereotype of a "strong leader." In contrast, our paper posits that organizations may hire some managers with dark personalities because their willingness to push ethical boundaries aligns with organizational objectives.

Accounting represents a functional area within organizations where ethical considerations are particularly critical, and where managers regularly face pressure to manage earnings to meet organizational objectives (Brown and Caylor 2005, Gowthorpe and Omat 2005, Graham et al. 2005, Cohen et al. 2010, Dichev et al. 2013, Kelly and Murphy 2019, Brazel et al. 2020, Suh et al. 2020). Because research shows that individuals with dark personalities are more likely to push ethical boundaries, we examine whether job candidates possessing these traits are more likely to be hired into accounting management positions when engaging in earnings management aligns 
with organizational objectives. Using several instrument validation studies and experiments, we demonstrate that experienced financial executives (corporate recruiters) are more likely to hire (recommend hiring) a senior accounting manager with dark personality traits when the organization faces earnings management pressure, despite this candidate being judged as a relatively poor job candidate along multiple other management and interpersonal dimensions. Our results also suggest that the proliferation of managers with dark personalities may be due to their perceived superior fit with organizations in which organizational financial objectives sometimes conflict with ethical obligations. The results reveal how the recruiting process may reinforce and exacerbate the ongoing economic, social, and political costs of earnings management.

To our knowledge, no prior study has examined the link between earnings management pressure and the hiring process in organizations. One possible reason for the absence of empirical evidence is that the necessary employment files are either confidential or completely unavailable. We circumvent this data availability problem by conducting experiments in which two hypothetical job candidates compete for a high-level accounting position. By design, there are no substantive differences between the candidates in terms of education, experience, or technical qualifications. However, the candidates differ in terms of their personality traits. The personality profile of one job candidate (referred to as "Candidate A") indicates many dark personality traits, including high narcissism, low idealism, high moral disengagement, high Machiavellianism, and high self-monitoring. Prior research indicates that these dark personality traits are associated with a predisposition to manage earnings (e.g., Murphy 2012, Ham et al. 2017). The personality profile of the other candidate (referred to as "Candidate B") indicates 
fewer dark personality traits. ${ }^{1}$ Appendix A shows the personality profiles of the job candidates, and Appendix B provides a summary of their development. In our experiments, we do not overtly state that either candidate does or does not manage earnings. Instead, participants must infer any such predisposition from the personality profiles.

In order to draw valid inferences from our experiments (i.e., that accounting managers with dark personalities may be favored for selection because their willingness to push ethical boundaries aligns with organizational objectives, even when those managers possess fewer desirable managerial attributes), it is necessary that the job candidate personality profiles convey two messages simultaneously - (1) Candidate A has dark personality traits associated with a predisposition to manage earnings while Candidate B does not and (2) Candidate B, relative to Candidate A, is considered to be an equally (or more) capable manager overall. Our instrument validation studies reveal that the personality profiles not only convey the above messages, but they demonstrate that Candidate B is viewed as a significantly better manager overall. Further, the instrument validation studies reveal that Candidate A, relative to Candidate B, is perceived to be more likely to engage in fraud (and other disreputable acts), and perceived to be less likely to maintain high ethical standards in the face of adversity. Our experiments also provide evidence that Candidate A is judged to be less likeable than Candidate B. All else being equal, these differences should forcefully push participants towards hiring Candidate B and away from hiring Candidate A. However, if participants place a sufficiently high value on one particular managerial attribute - the ability and willingness to manage earnings - Candidate A will be

\footnotetext{
${ }^{1}$ Our research instruments vary whether the job candidates are referred to as Candidate A or Candidate B (see Section 3). For expositional simplicity, we refer to the job candidate who has more dark personality traits as Candidate A and the job candidate who has fewer dark personality traits as Candidate B.
} 
selected over Candidate B despite the fact that Candidate A possesses a constellation of generally negative personality traits and predispositions.

We conduct three separate experiments to test our research hypothesis from different angles. While each of our experiments carries the same weight in hypothesis testing, each contains design features that help us to (1) capture the richness of the environment in which important hiring decisions are made in practice and (2) rule out potential alternative explanations for our results. We use different sets of participants (financial executives, individuals with prior finance/accounting coursework and work experience, and professional recruiters), different operationalizations of earnings management pressure (public company facing capital market pressure versus non-profit foundation, and private company facing IPO versus not), and multiple measures of candidate preference (hiring decisions, referral decisions, and person-organization fit assessments). Our sequence of experiments therefore capitalizes on the strengths of a multiple experiment approach as described by Asay et al. (2019).

In each experiment, participants learn that an organization is seeking to fill a high-level accounting management position. The job candidate who is hired to fill the position will oversee accounting operations and make judgments and decisions related to financial reporting. ${ }^{2}$ In Experiment 1, we manipulate the type of hiring organization, and financial executive participants assume the role of an executive at either a for-profit public company or a non-profit foundation. They evaluate the organizational fit and likelihood of hiring Candidate A as significantly higher at the for-profit public company, suggesting that the perceived fit between dark personality traits and earnings management pressure significantly impacts hiring decisions. In Experiment 2, we

\footnotetext{
${ }^{2}$ As we discuss later, the role of the chosen candidate in the organization does not extend beyond the accounting function. As a result, the perceived capability of a job candidate to engage in business activities that create firm value are only relevant insofar as those capabilities translate into managing the accounting function.
} 
hold the hiring organization constant (a for-profit private company) with financial statement purpose manipulated between participants, and participants assume the role of the company owner. When financial statements are used for valuation as opposed to owner monitoring, participants rate Candidate A as significantly more likely to be hired. In Experiment 3, we hold the hiring organization constant (a for-profit public company that faces earnings management pressure) with candidate personality profile manipulated between participants, and professional recruiting participants make a referral decision for this company. They indicate a higher likelihood of referring Candidate A for the position, suggesting that candidates with dark personalities may already be preselected early in the hiring process. Taken together, our results suggest that in two different company contexts and across three different groups of participants, senior accounting managers with dark personalities are more likely to be matched to positions that require pushing ethical boundaries.

Our research makes three interrelated contributions to the accounting and business ethics literatures. First, we provide evidence relevant to answering a provocative question - are individuals who are most likely to engage in earnings management also the individuals who are most likely to ascend to positions of power and authority in the accounting function of organizations? This question has been asked for decades, but not investigated. For example, Rosenzweig and Fischer (1994, p. 33) speculate that accountants "who have loose standards regarding earnings management may be more likely to be promoted" and that lower-level employees "will learn quickly that the route to success in the organization is not facilitated by truthful reporting." Related to this claim, Parfet (2000, p. 485-486) contends that earnings management "is expected and demanded, both inside and outside of business, by all stakeholders 
in the capital market." We provide the first evidence relevant to addressing the descriptive validity of these claims.

Second, our results add to research on the relation between dark personalities and managerial success. Some researchers suggest that individuals who have dark personality traits may ascend to positions of power and authority in organizations because they are, perhaps incorrectly, viewed as superior leaders (Rosenthal and Pittinsky 2006, Brunell et al. 2008, Schnure 2010) or because, through self-promotion and impression management, they may convince evaluators that their job performance is better than it really is (Caldwell and O'Reilly 1982, Judge et al. 2006, Zettler and Solga 2013). Our results suggest that evaluators may have entirely correct beliefs about an individual's capabilities/skills/predispositions, and that the propensity for dark personalities to push ethical boundaries in and of itself increases fit with certain organizations.

Third, we provide evidence relevant to assessing the efficacy of regulators' current approach to curtailing earnings management (i.e., increased amounts of regulation). Our results suggest that regulatory efforts to curtail earnings management may achieve greater success if those efforts simultaneously target the cultural dimension of earnings management that is played out through the employee selection process. Indeed, the former chairman of the SEC, Arthur Levitt, hinted at doing more than enacting additional regulations when he called for "nothing less than a fundamental cultural change on the part of corporate management as well as the whole financial community" to eliminate earnings management (Levitt 1998, p. 18). However, it is hard to solve a problem when a major underlying cause is not well illuminated. Our research helps to illuminate why earnings management stubbornly persists despite regulatory efforts to curtail that behavior. 
The remainder of this paper proceeds as follows. Section 2 develops our main research hypothesis. Section 3 presents two instrument validation studies that help to validate certain features of the personality profiles used in our three experiments. Sections 4, 5, and 6 discuss Experiments 1,2, and 3, respectively, which contain the main empirical tests of our research hypothesis. Section 7 provides a conclusion and suggestions for future research in this area.

\section{Theory and Hypothesis}

\subsection{Earnings Management Incentives and Trends}

Competition is a powerful force - it favors organizations that use efficient operating procedures and contracting techniques and weeds out organizations that do not (Alchian 1950, Zimmerman 2003, Brickley et al. 2009). In competitive economic systems, business practices that survive over time tend to yield benefits in excess of their costs or those practices would eventually cease (Alchian 1950, Watts and Zimmerman 1986, Zimmerman 2003, Brickley et al. 2009). Many organizations face considerable pressure to achieve various earnings-related objectives, and some professionals may engage in earnings management to achieve those objectives (Graham et al. 2005, Dichev et al. 2013). ${ }^{3}$ The practice of earnings management has survived for many decades (Healy and Wahlen 1999, Dechow and Skinner 2000, Cohen et al. 2008) and continues to occur to this date (Dichev et al. 2013), indicating that the benefits of earnings management exceed the associated costs, on average. There is also indirect evidence that the market rewards (or fails to penalize) earnings management. Bartov et al. (2002) find that the market reward for meeting or beating analysts' earnings forecasts is only marginally affected by whether organizations manage earnings to meet those forecasts. Similarly, Das et al. (2011)

\footnotetext{
${ }^{3}$ Examples of earnings-related objectives include, but are not limited to, avoiding negative earnings surprises (Brown and Caylor 2005), avoiding losses and earnings decreases (Burgstahler and Dichev 1997), and reporting smooth earnings (Graham et al. 2005).
} 
find that, while there is a market penalty for managing earnings to meet an earnings threshold, the market reward exceeds the market penalty.

Despite potential benefits of managing earnings, there are potential drawbacks. Earnings management creates a permissive ethical climate (Merchant and Rockness 1994, Jensen 2001, Albrecht, et al. 2012), and seemingly innocuous forms of earnings management may precipitate more extreme forms of earnings management, including outright fraud (Schrand and Zechman 2012). In addition, regulators and practitioners have adopted the view that earnings management is pervasive and problematic. Levitt (1998) frames earnings management as one of the most fundamental threats to efficient and liquid markets, highlights the loss of unbiased information and communication with shareholders, and discusses how numerous regulators attempt to work together to strengthen auditing and financial reporting oversight to prevent earnings management. Dechow and Skinner (2000) indicate that accounting researchers appear to have more permissive views of earnings management than regulators and practitioners, who perceive earnings management as particularly damaging to investors. Consistent with this view, the Sarbanes-Oxley Act of 2002 (SOX) requires company executives to certify that the financial statements are complete and accurate, and it also requires public companies to adopt a code of ethics (or explain why a code has not been adopted). Many of the expected benefits of SOX have been realized. For example, SOX has improved (1) governance (Linck et al. 2009, Cohen et al. 2010, Carcello et al 2011), (2) the ethical climate (Wagner and Dittmar 2006, Albrecht et al. 2012), (3) audit committee efficacy (DeZoort et al. 2008), and (4) earnings quality (AshbaughSkaife et al. 2008). SOX has also resulted in more conservative earnings (Lobo and Zhou 2006, Iliev 2010) and improved market liquidity (Jain et al. 2008). Further, there are potentially large 
wealth-related consequences for executives when accounting-related improprieties are uncovered (Dechow et al. 1996, Desai 2006, Feng et al. 2011).

Although some forces may discourage earnings management, there are labor market forces that may promote it. Individuals in the accounting labor market who are able and willing to manage earnings compete against other members of the labor market who may be unable or unwilling to manage earnings. Individuals who possess the abilities demanded by prospective employers are likely to successfully compete for higher-level positions, while individuals who lack those abilities are likely to languish in lower-level positions. The survey results of Graham et al. (2005) suggest that failure to meet an earnings target is viewed by the labor market as a managerial failure, and repeatedly missing an earnings target inhibits a manager's labor market mobility. Professionals seem to understand the importance that investors and others ascribe to earnings, and evidence indicates that managers sometimes find it necessary to manage earnings (Graham et al. 2005, Dichev et al. 2013).

Scholars have speculated that incentives present in many organizations may result in a striking outcome - individuals who are most likely to manage earnings are also the ones who are most likely to ascend to positions of power and authority in the accounting function (Bruns and Merchant 1990, Merchant and Rockness 1994, Rosenzweig and Fischer 1994, Fuller and Jensen 2002). This speculation is broadly compatible with a rational labor market matching process whereby certain types of people are attracted to, recruited and selected by, and continue employment in certain types of organizations (Schneider 1987). The management literature indicates that it is desirable for organizations to hire individuals who fit the work environment (Edwards 2008), which helps organizations maintain a workforce that is committed to achieving key objectives (Kristof 1996). As such, when making important hiring decisions, organizations 
first identify what the position requires in terms of employee knowledge, skills, abilities, and other attributes (e.g., personality traits) and then hire an individual who possesses those desired attributes (Schneider 2001).

\subsection{Dark Personalities and Leader Behavior}

Prior research indicates that individuals with dark personality traits may also possess attributes considered desirable in a business context, such as confidence, perceived creativity, ability to manage impressions, and aggressive pursuit of business opportunities (Caldwell and O’Reilly 1982, Raskin et al. 1991, Chatterjee and Hambrick 2007, Brunell et al. 2008, Babiak et al. 2010, Goncalo et al. 2010, Nevicka et al. 2011, Zettler and Solga 2013, Ong et al. 2016). For example, narcissistic managers are more likely to be seen as inspirational, creative, and better able to cope with organizational change (Deluga 1997, Maccoby 2007, Spangler et al. 2012). Consistent with these perceptions, narcissists are more likely to emerge as leaders (Judge et al. 2006, Wille et al. 2013), and narcissistic CEOs obtain higher compensation (O'Reilly et al. 2014). Similarly, Machiavellians may be more likely to rise to leadership positions (Spurk et al. 2016) and may be more successful in certain positions, as evidenced by superior performance for high-Machiavellian stockbrokers (Shultz 1993, Aziz et al. 2002). High self-monitors likewise obtain more promotions and more prestigious positions at other firms (Kilduff and Day 2004), in addition to enjoying higher performance ratings on the job (Mehra et al. 2001). Babiak (1995) suggests that even psychopaths may be able to manipulate their way to organizational success. Finally, Furnham et al. (2012) find that individuals with dark personalities self-rate as having better development and success at work. While some research takes a more balanced view of dark personalities, discussing both pros and cons of leaders with these traits (Rosenthal and Pittinsky 2006), a larger stream of literature presents evidence of negative consequences. 
Despite the rise of leaders with dark personalities and the previously discussed evidence of higher pay, performance evaluations, and promotion potential, research suggests these individuals often have destructive effects on their organizations. Narcissistic leaders are more likely to violate company ethical standards (O’Connor et al. 1995, Blickle et al. 2006) and create unhappy workplaces (Blair et al. 2008). Much of their perceived creativity is likely a façade (Goncalo et al. 2010), and they inhibit the performance of groups they lead (Nevicka et al. 2011). Narcissists may even be skilled enough at manipulation and self-promotion that many of the promotions they obtain are undeserved (Hogan et al. 1990). Machiavellian leaders have also been shown to decrease trust and employee wellbeing in the workplace (Gkorezis et al. 2015, Belschak et al. 2018), and to worsen the ethical climate in their organizations (Den Hartog and Belschak 2012). High self-monitors produce negative workplace consequences including unintended employment turnover (Allen et al. 2005) and less accurate performance evaluation and pay decisions for subordinates (Jawahar 2001). Finally, psychopaths display a tendency to abuse employees and create unhealthy environments (Boddy et al. 2015), as well as to reduce corporate performance and employee creativity (Boddy 2017). In addition to these previously examined negative organizational effects, leaders with dark personality traits are generally viewed as being inconsistent with multiple cultures' perceptions of positive ethical leadership (Eisenbeiss and Brodbeck 2014). Further, the negative effects of dark personalities on organizations also extends into the particular realm of earnings management and accounting choices.

\subsection{Dark Personalities and Earnings Management}

Prior research utilizing both theory and archival methods suggests that dark personality traits impact the propensity to push ethical boundaries on the job, including in the realm of 
accounting and reporting. Duchon and Drake (2009), Amernic and Craig (2010), and Boddy (2011) all form theoretical arguments to reinforce the link between managers' narcissism and willingness to push ethical boundaries. Cohen et al. (2010) analyze cases of past fraud and conclude that manager attributes such as narcissism, autocratic leadership style, and reputation concern represent fraud risk factors. Rijsenbilt and Commandeur (2013), Olsen et al. (2014), Ham et al. (2017), and Buchholz et al. (2019) all use large datasets to show that CEO and CFO narcissism are positively associated with earnings management and fraud. Van Scotter and Roglio (2020) analyze prior scandals and find an association between dark personality traits and CEO misconduct.

Experimental accounting research similarly suggests that personality traits provide a glimpse into the accounting-related behaviors that managers display on the job. For example, Murphy (2012) finds that high Machiavellian individuals are more likely to misreport performance. Ham et al. (2017) find that narcissistic individuals are more likely to misreport monetary allocations assigned to them. Johnson et al. (2013) indicate that auditors view client manager narcissism as a fraud risk indicator. Greenfield et al. (2008) find that high relativists are more likely to manage earnings than high idealists. Consistent with this finding, Elias (2002) indicates that accountants who are high on trait relativism and low on trait idealism view earnings management as more ethically acceptable than accountants who have other ethical orientations. Seybert (2010) finds that high self-monitors are more likely to engage in real earnings management. Chung and Hsu (2017) demonstrate that individuals with lower cognitive moral development misreport to a greater extent. Finally, Majors (2016) shows that individuals with the dark personality traits of Machiavellianism, narcissism, and psychopathy report more aggressively. In summary, a variety of prior accounting studies indicates that a number of 
observable and measurable personality traits, particularly dark personality traits, predict the willingness of individuals to push ethical boundaries in the accounting context.

We base the selection of dark personality traits for Candidate A on the prior research linking traits to unethical behavior. Candidate A's traits reflect high narcissism, Machiavellianism, and self-monitoring, as well as moral disengagement and relativism, a "powerful others" locus of control, and the ability to rationalize behaviors. In particular, Candidate A likes to be the center of attention and appreciates flattery, thinks that leadership requires pleasing those in positions of power, believes morals can differ across people and situations, and will change his/her behavior to suit different people in different situations. Candidate A also believes results are more important than process, rules should be rewritten when necessary, and subordinates should only receive limited information. Candidate A is willing to take actions inconsistent with personal core values, can justify these actions after the fact, and accepts that his/her own decisions may negatively impact others. Although some of these traits in isolation may represent potential positives (e.g., changing behaviors to suit different people and situations), we anticipate that Candidate A, compared to Candidate B, will be viewed as a worse manager when considering the overall collection of attributes. ${ }^{4}$

Furthermore, the candidates may differ in terms of likeability due to their different personality traits. For example, Candidate A has some traits that people might consider to be unappealing (e.g., Candidate A is narcissistic), while Candidate B has traits that people might consider to be commendable (e.g., Candidate B is an idealist). Thus, we anticipate that Candidate A will be

\footnotetext{
${ }^{4}$ Participants in our second validation study rate Candidate A as worse at managing people, managing the work environment, work habits, and interpersonal traits. Although our particular personality profile appears to convey negative information about Candidate A's overall managerial qualities, our studies cannot rule out that some leaders with dark personalities have other desirable attributes in certain organizational contexts.
} 
viewed as less likeable than Candidate B because Candidate A possesses more dark personality characteristics than Candidate B.

In order for accounting managers who have dark personality traits associated with a predisposition to manage earnings to propagate in the labor market, employers must have the ability to identify those individuals. Research in management emphasizes the importance of assessing person-organization (PO) fit during the employee selection process to help distinguish between similarly qualified job candidates (Schneider 1987, Chatman 1989, Rynes and Gerhart 1990, Cable and Judge 1997, Edwards 2008) by, for example, evaluating job candidate personality profiles (Stabile 2002, Krell 2005, Baez 2013). In addition, executive recruitment firms claim to assess job candidate personality traits before referring a candidate to a client. ${ }^{5} \mathrm{PO}$ fit reflects the perceived congruence between the organization's culture, values, goals, and norms and the job candidate's personality, values, goals, and attitudes (Kristof 1996). Combining prior accounting research linking dark personalities to earnings management and other accounting improprieties with research on PO fit, we argue that a company with higher earnings management pressure could judge a candidate with dark personality traits as providing a better fit due to the candidate's perceived willingness to push ethical boundaries.

This discussion highlights several interrelated factors leading to our hypothesis. First, many organizations face considerable pressure to manage earnings. Second, earnings management is, at minimum, tacitly allowed by many organizations as an efficient means to achieve earnings-related objectives. Third, an accounting professional's ability and willingness

\footnotetext{
${ }^{5}$ See, for example, the websites of two large executive recruitment firms - Lucas Group and Korn Ferry International. Lucas Group states that “Our detailed interviewing process enables Lucas Group's HR recruiters to precisely match qualifications, cultural fit and long-term compatibility, and they ensure lasting and successful placements..." Korn Ferry states that “...behavior-based approaches to interviewing consistently lead to better results in identifying the right talent for the job."
} 
to manage earnings is part of the overall skillset they provide. Fourth, personality traits may be informative about an individual's accounting-related behaviors and predispositions, which are manifest in on-the-job performance. Fifth, organizations seek to match the demands of the positions they fill with the skills, capabilities, and personalities of the individuals whom they hire to fill those positions. This discussion leads to our main research hypothesis, stated in alternative form:

Hypothesis: As organizational pressure to manage earnings increases, job candidates possessing more dark personality traits are more likely to be hired for accounting manager positions than job candidates possessing fewer dark personality traits.

\section{Instrument Validation Studies}

\subsection{Purpose of Studies}

The instruments that we use to test our research hypothesis provide participants with information about the personality traits of two candidates who are being considered for a highlevel accounting position at an organization. The personality traits of the candidates are embedded within the personality profile section of the applicant dossier. Appendix A provides the personality profiles of the two hypothetical job candidates, and Appendix B summarizes how we developed the profiles. The candidate dossiers contain a variety of information in addition to the personality profile, such as education, work experience, and certification. We do not overtly state that either job candidate does or does not manage earnings. Instead, participants themselves must infer any such predisposition from the personality profiles. ${ }^{6}$

\footnotetext{
${ }^{6}$ An alternative approach would be to overtly state that the job candidate does or does not manage earnings. This approach seems problematic because there is no evidence that job candidates and employers talk about earnings management in such an overt way.
} 
One job candidate has more dark personality traits, which should be associated with a predisposition to manage earnings (this candidate is referred to as "Candidate A"), while the other candidate has fewer dark personality traits (this candidate is referred to as "Candidate B"). The purpose of the two instrument validation studies reported in this section is to show that Candidate $\mathrm{A}$, relative to Candidate $\mathrm{B}$, is perceived by our participants as being predisposed to manage earnings (Instrument Validation Study A) but is not perceived by our participants to be a better overall manager (Instrument Validation Study B).

\subsection{Instrument Validation Study A}

\subsubsection{Participant Recruitment}

We randomly selected 2,500 professionals from U.S. companies on the LexisNexis Academic Executive List. ${ }^{7}$ Each of the professionals had a title indicating involvement in the accounting and/or finance function. The study was administered through Qualtrics. We contacted business professionals in two ways - (1) an initial email and a follow-up email approximately one week later and (2) a letter to the street address of each individual who had a valid email address. Of the 2,500 business professionals we contacted, 344 had an invalid email/street address. A total of 59 experienced business professionals participated in this study, resulting in a response rate of 2.74 percent. $^{8}$

\subsubsection{Instrument}

Participants are provided with background information about a public company that is trying to fill a senior accounting manager position. Participants learn that company personnel

\footnotetext{
${ }^{7}$ We use this same database in Instrument Validation Study A and Experiment 1, each time randomly selecting a new, non-overlapping sample of business professionals.

${ }^{8}$ The demographics for participants in this instrument validation study are very similar to those in Experiment 1 (see Table 2 for Experiment 1 demographics). For brevity, we do not tabulate demographic information for Instrument Validation Study A.
} 
have evaluated a large pool of candidates and that two finalists have been chosen. For each candidate, the instrument provides information about (1) education and certification, (2) work experience, and (3) the job candidate personality profile. ${ }^{9}$ By design, the candidate summaries are extremely similar in terms of the information conveyed by items (1) and (2), but they differ in terms of the information conveyed by item (3). ${ }^{10}$ The instrument defines the phrase "earnings management" to give participants a common understanding of what this phrase generally means. Our definition is a composite definition from the academic literature (Schipper 1989, Healy and Wahlen 1999, Dechow and Skinner 2000), which is as follows:

Senior accounting managers frequently make accounting estimates and accounting-related professional judgments. These estimates and judgments can have a large influence on the amounts reported in a firm's financial statements, including net income. Ideally, senior accounting managers make estimates and judgments in ways that produce accurate and transparent financial statements. In some cases, senior accounting managers desire to achieve a particular level of earnings, and they may alter their estimates and judgments to get that outcome. This is called "earnings management." When senior accounting managers manage earnings, the main consequence is that the firm's financial statements do not accurately reflect the firm's true economic performance.

Participants then respond to questions that elicit their views about each job candidate (see Table 1 for questions). Participants respond on a 100-point sliding scale, with the left endpoint labeled "Definitely Candidate A" and the right endpoint labeled "Definitely Candidate B."

\subsubsection{Results}

Table 1 provides participant responses to 14 questions about earnings management and moral/ethical pliability. Participants have strongly polarized views, as indicated by the fact that

\footnotetext{
${ }^{9}$ The instrument informs participants that as part of the company's employment application process, each candidate was required to complete a personality assessment questionnaire designed to elicit the behaviors, beliefs, and values that the job candidate is most likely to exhibit on the job.

${ }^{10}$ In our Instrument Validation Studies and Experiments 1 and 2, participants view the job candidate personality profiles side-by-side. When presenting the profiles, we vary the order in which they are presented. For half of the participants, the candidate with more dark personality traits is presented in the first column and the other candidate is presented in the second column (and vice-versa). The first candidate is always labeled Candidate $\mathrm{A}$ and the second candidate is always labeled Candidate B. There are no order effects in any study (all p $>0.20$ ).
} 
all responses are significantly different from the midpoint of the scale (all $\mathrm{t} \geq 7.82$, all $\mathrm{p}<0.01$ ). Participants believe that Candidate A (the candidate with more dark personality traits) is most likely to initiate efforts to manage earnings (Question 1), most likely to encourage others to manage earnings (Question 4), most susceptible to pressure from others to manage earnings (Question 5), most likely to believe that the positive consequences of earnings management justify engaging in that behavior (Question 7), most likely to participate in types of earnings management that would be considered fraud (Question 8), most likely to engage in a series of seemingly harmless accounting decisions that lead to serious accounting infractions, including fraud (Question 11), and most likely to relax their standards of ethical behavior in the face of professional gain (Question 13). Thus, we find that Candidate A, relative to Candidate B, is perceived to be more likely to engage in earnings management and related accounting behaviors.

In contrast, participants believe that Candidate B (the candidate with fewer dark personality traits) is least likely to go along with existing efforts to manage earnings (Question 2), most uncomfortable managing earnings (Question 3), most likely to steer others away from managing earnings (Question 6), most likely to follow a company code of ethics that prohibits earnings management (Question 9), most likely to set an exemplary standard of ethical behavior (Question 10), most likely to hold himself/herself to the highest ethical standards (Question 12), and least likely to relax their own standards of ethical behavior in the face of professional hardship (Question 14). Thus, we find that Candidate B, relative to Candidate A, is perceived to be less likely to engage in earnings management and related accounting behaviors.

\subsubsection{Discussion}

Participants appear to interpret the job candidate personality profiles in the manner we expect. Candidate A, who possesses more dark personality traits relative to Candidate B, is 
perceived as being predisposed to manage earnings. At the same time, Candidate A, relative to Candidate B, is also perceived to be more likely to fall prey to accounting-related ethical infractions (and more likely to ensnare others in those same ethical infractions), which, even if initially small, could lead to serious infractions later, including outright fraud. Concurrently, Candidate B, who possesses fewer dark personality traits relative to candidate A, is perceived to be largely immune to such temptations and is perceived to be unlikely to allow accountingrelated ethical infractions to propagate in organizations. As a result, organizations that hire Candidate A over Candidate B are exposed to certain negative consequences if the earnings management behavior to which Candidate A is predisposed actually unfolds.

\subsection{Instrument Validation Study B}

\subsubsection{Participant Recruitment}

We recruited participants from Amazon's Mechanical Turk platform (see Rennekamp 2012). There are 99 participants who average approximately 33 years of age and 13 years of work experience. ${ }^{11}$ We compensated each participant $\$ 2.00$ to complete this study, which takes approximately 15 minutes. The age and experience profiles of these participants suggest that they are suitable for the task that we have them perform.

\subsubsection{Instrument}

Participants are informed that a company's senior accounting manager recently retired and that the company has hired a new senior accounting manager to fill the position. Participants then learn about the company's financial objectives, which the accounting manager is expected to help achieve. These financial objectives include achieving profit goals, avoiding negative

\footnotetext{
${ }^{11}$ The concept of a response rate is not relevant in this study. We sought 100 participants and once that threshold number of participants was met, the study was closed. There was one individual who requested payment but did not complete the study, which is why the study has 99 qualified participants rather than 100 .
} 
earnings surprises, reporting smooth earnings, and displaying financial strength and stability. ${ }^{12}$ Participants are also informed that employees of the company are committed to achieving the financial objectives. Participants then learn about the senior accounting manager's role within the company, which includes overseeing accounting operations and making important judgments and decisions related to financial reporting.

Next, participants learn that two qualified job candidates were selected as finalists for the position. Participants then receive the job candidate summaries, which provide information about each candidate's (1) education and certification, (2) work experience, and (3) personality. By design, the candidate summaries are extremely similar in terms of the information conveyed by items (1) and (2), but they differ substantially in terms of the information conveyed by item (3). Participants then learn that either Candidate A was hired or that Candidate B was hired (this is our between-subjects manipulation). Participants respond to 27 statements that elicit attributions about why the particular candidate was hired. The statements are clustered around six managerial/personal skills - managing people, managing the work environment, managing activities, work habits, interpersonal traits, and managing earnings to achieve desired accounting outcomes. We have participants respond on a 100-point scale (the left endpoint is labeled "Definitely Disagree" and the right endpoint is labeled "Definitely Agree"). Representative statements, one for each of the managerial/personal skills, are provided below (these statements are for the condition in which participants learn that Candidate A was hired over Candidate B):

1. Candidate A will provide more constructive feedback to staff than Candidate B (managing people dimension)

2. Candidate A will maintain staff morale better than Candidate B (managing the work environment dimension)

\footnotetext{
12 The financial objectives presented to participants are common objectives of public companies, which may create pressure to manage earnings (Graham et al. 2005).
} 
3. Candidate A will plan activities of the accounting department better than Candidate B (managing activities dimension)

4. Candidate A will work more efficiently than Candidate B (work habits dimension)

5. Candidate $\mathrm{A}$ is more pleasant than Candidate $\mathrm{B}$ (interpersonal traits dimension)

6. Candidate A will more likely remove any roadblocks to achieving profit goals than Candidate B (managing earnings to achieve desired accounting outcomes dimension)

\subsubsection{Results}

Figure 1 graphs mean responses by condition. We find that the mean responses for each managerial/personal skill type are significantly different between conditions (all $p \leq 0.01)$ except for the mean responses related to managing activities $(p=0.78)$. A difference in the means implies that participants attribute the organization's hiring decision to differential candidate abilities in a given managerial/personal skill. For example, participant responses to the statements about managing people have a mean of 54.04 when participants learn that Candidate A was hired and a mean of 70.79 when participants learn that Candidate B was hired. The significant difference between conditions suggests that participants attribute the hiring of Candidate B to relatively strong capabilities at managing people. The same inference can be drawn about Candidate B relative to Candidate A with respect to managing the work environment, work habits, and interpersonal traits.

There is a dramatic reversal with respect to statements related to managing earnings to achieve accounting outcomes. The mean is 76.68 when participants learn that Candidate A was hired and only 54.27 when participants learn that Candidate B was hired. This suggests that participants attribute the hiring of Candidate A to his/her comparatively strong capabilities at managing earnings to achieve accounting outcomes. In summary, Candidate B is perceived to be a better manager than Candidate A on four of the six managerial/personal skills, and Candidate A 
is perceived to be a better manager than Candidate B on only one of the six managerial/personal skills - managing earnings to achieve accounting outcomes. We conclude that the dark personality traits embedded in the profile of Candidate A signal a predisposition to manage earnings but do not simultaneously signal superior managerial/personal skills in other areas.

\subsubsection{Discussion}

The results of Instrument Validation Study B indicate that Candidate A's personality profile conveys the message that Candidate $\mathrm{A}$ is predisposed to manage earnings without concurrently conveying the message that Candidate $\mathrm{A}$ is a better overall manager than Candidate B. Further, this study suggests that Candidate B is considered to be a better overall manager than Candidate A on the important work-related dimensions we measure, which makes it reasonable to expect that Candidate B will experience greater accounting labor market success than Candidate A. As a consequence, it appears that there is a substantial hurdle that Candidate A must overcome in order to be hired over Candidate B for a high-level accounting position - the organization must be willing to forego hiring the job candidate who is judged to be the better overall manager in order to hire the job candidate who is predisposed to manage earnings. To the extent that Candidate A is favored over Candidate B, the accounting labor market would seem to value one managerial capability above the others - the ability and willingness to manage earnings that is signaled by dark personality traits.

\section{Experiment 1}

\subsection{Purpose}

The purpose of this experiment is to empirically test our research hypothesis using company executives who have very substantial experience making hiring decisions. We use the context of a for-profit public company versus a non-profit foundation to test whether the hiring 
preference for a candidate with dark personality traits is impacted by the earnings management pressure faced at public companies.

\subsection{Participant recruitment}

We randomly selected 5,000 professionals from U.S. companies on the LexisNexis Academic Executive List. Each of the professionals has a job title indicating involvement in the accounting and/or finance function at their organization. The experiment was administered via Qualtrics. We contacted professionals in two ways - (1) an initial email and a follow-up email approximately one week later and (2) a letter to the street address of each individual who had a valid email address. Of the 5,000 business professionals we contacted, 749 had an invalid email/street address. A total of 113 experienced business professionals participated in this experiment, resulting in a response rate of 2.66 percent.

\subsection{Demographics}

Demographic information is reported in Panel A of Table 2. Participants' mean age is 50.71 years and their mean work experience is 27.74 years. Participants indicate that they are familiar with the duties of accounting managers (mean 8.83 on a 10-point scale with higher responses indicating greater familiarity) and with evaluating job candidates for purposes of making hiring decisions or hiring recommendations (mean 9.04 on a 10-point scale with higher responses indicating greater familiarity). The mean employee headcount at participants' organizations is 5,902.50. Approximately 67 percent of participants have experience working for a public company, and approximately 60 percent of participants have experience working for a non-profit organization. The mean number of accounting and finance courses taken is 11.65 and 5.76, respectively. ${ }^{13}$ Approximately 53 percent of participants are male. Participants generally

\footnotetext{
${ }^{13}$ These questions did not specify whether "courses" refers to college courses or continuing professional education courses. These means may be lower if the questions specified formal college courses.
} 
hold titles indicating a high level of professional achievement (i.e., chief financial officer, chief accounting officer, controller, etc.).

\subsection{Instrument}

Participants take the role of an executive who learns that the senior accounting manager at their employer has decided to retire. The executive is in the process of finding a successor for the senior accounting manager. Participants are randomly assigned to either the for-profit public company condition or the non-profit foundation condition. In the for-profit public company condition, participants learn about the company's financial objectives, which include meeting profit goals, avoiding negative earnings surprises, reporting smooth earnings, and showing financial strength and stability. ${ }^{14}$ In the non-profit foundation condition, participants learn about the foundation's financial objectives, which include fulfilling donor directives, maintaining proper stewardship of donations, controlling operating costs, and transparency related to reporting activities. ${ }^{15}$ All participants are informed that (1) employees are committed to achieving the financial objectives, (2) there is a belief among employees that failure to achieve financial objectives will adversely affect the company/foundation, and (3) the senior accounting manager's particular role within the company/foundation includes, among other things, overseeing accounting operations and making important judgments and decisions related to financial reporting.

\footnotetext{
${ }^{14}$ It is noteworthy that these financial objectives are neither extreme nor stylized. Rather, they are drawn from prior research documenting earnings-related pressures experienced by managers of many companies (e.g., Burgstahler and Dichev 1997, Brown and Caylor 2005, Graham et al. 2005). Presenting participants with an ecologically valid set of financial objectives improves the external validity of this experiment.

${ }^{15}$ We could have fully crossed organizational type and financial objectives in a $2 \times 2$ design (instead of identifying the two cells in the $2 \times 2$ design that allow us to most efficiently test our hypothesis). We chose not to pursue a $2 \times 2$ design for two reasons. First, the two organizational types (for-profit and non-profit) are paired with appropriate financial objectives in the two cells we consider. If we used a $2 \times 2$ design we would have to, for example, pair a non-profit organization with for-profit financial objectives and vice-versa, which would reduce the ecological validity of our manipulations. Second, we would have to populate twice the number of cells with highly experienced practicing managers, which are generally difficult participants to recruit.
} 
By varying the type of business entity and related financial reporting objectives, we manipulate the extent to which participants feel that the entity faces pressure to manage earnings. Notice that in a non-profit foundation, compared to a for-profit company, there is comparatively low pressure to manage key financial reporting metrics. ${ }^{16}$ There is no disagreement that for-profit public companies face a variety of earnings-related pressures (Healy and Wahlen 1999), so manipulating the type of entity seeking to hire a senior accounting manager allowed for the cleanest test of our hypothesis.

Participants are informed that company/foundation personnel have evaluated a large pool of job candidates and that two finalists have been chosen (referred to as "Candidate A" and "Candidate B"). The task of our participants is to indicate which candidate they believe the company/foundation will hire. The materials explain that both candidates are highly qualified for the position, performed well in their interviews, were liked by the interviewers, displayed strong communication skills, and received excellent recommendations from previous employers. Participants also receive job candidate summaries which provide information about (1) education and certification, (2) work experience, and (3) the job candidate personality profile. By design, the candidate summaries are extremely similar in terms of the information conveyed by items (1) and (2), but the summaries differ substantially in terms of information conveyed by item (3). ${ }^{17}$

\footnotetext{
${ }^{16}$ Research by Chen (2016) and Yetman and Yetman $(2012,2013)$ suggests that non-profit entities face some pressure to manage financial reports. As a result, it is possible that there may be no difference in hiring decisions between the for-profit public company condition and the non-profit foundation condition. At the same time, there is no indication in the extant literature that the intensity of pressure to manage financial reports in the non-profit sector matches the intensity of the pressure to manage financial reports in the for-profit sector.

${ }^{17}$ Efforts to equalize education and work experience between the job candidates were extensive. Both candidates (1) worked at a Big 4 accounting firm, (2) achieved the rank of manager, and (3) have undergraduate and graduate degrees in accounting from respected public universities. Participants also respond to a series of salience checks which take the form of true/false questions. For example, one true/false question states that "Both candidates received excellent recommendations from previous employers" while another question states that "Both candidates possess similar qualifications for the senior accounting manager position." Participants correctly respond to the salience check questions between 85 percent and 100 percent of the time. The inferences and conclusions of this experiment are unaffected by removing participants who missed salience checks.
} 
While the job candidates are very different, it is important to note that the instrument makes it clear that the role of the chosen candidate in the organization does not extend beyond the accounting function. The position being filled is a senior accounting manager position with financial reporting responsibilities. However, the hired individual will have no role in managing functional areas of the organization outside of accounting. As a result, the perceived capability of a job candidate to engage in business activities that create firm value are only relevant insofar as those capabilities translate into running the accounting function.

Because decades of prior research have established PO fit as an antecedent to important hiring decisions (e.g., Cable and Judge 1997), we have participants evaluate PO fit before making their hiring decision. Participants respond to nine PO fit questions (referred to as "fit questions" below) that we develop from prior literature (see Appendix C). Because there are no substantive differences between the candidates other than their personality traits, PO fit assessments reflect participants' perceptions about the compatibility between the entity's financial objectives and the candidates' personalities. Participants respond to the fit questions on a 100-point sliding scale. The left endpoint labeled "Definitely Candidate A" and the right endpoint labeled "Definitely Candidate B."18

Participants then respond to the job candidate selection question, which states "Based on your assessment of the candidates and the information about the Company (Foundation), which candidate do you believe the Company (Foundation) will most likely hire to fill the senior accounting manager position?" ${ }^{19}$ Participants respond on the same 100-point sliding scale as the

\footnotetext{
${ }^{18}$ For all of the questions using the 100-point sliding scale, the slider starts at the mid-point of the scale. Participants must move the slider in either direction to continue. Once the slider is moved in either direction, the mid-point of the scale cannot be selected. Participants do not see numerical values on the scale, but we translate their scale position to a numerical value between 1 and 100, inclusive. In the instructions, participants are informed that moving the slider closer to one end of the scale or the other indicates the strength of their response.

${ }^{19}$ Participants may respond to questions in ways that they believe are "correct" or socially acceptable (Fisher 1993). Social desirability bias may influence variable means and relationships among variables (Zerbe and Paulhus 1987).
} 
fit questions. We analyze both a continuous response and a dichotomous response. The dichotomous response is coded as 0 if the response is below the mid-point of the scale (a preference for Candidate A) and 1 if the response is above the mid-point of the scale (a preference for Candidate B). Next, we elicit participants' responses to the following question: "Based on the information presented in the job candidate profile summary report for Candidate A, how much did you like Candidate A?" We ask the same question about Candidate B. Participants respond on a 10-point scale with the left endpoint labeled "Definitely disliked" and the right endpoint labeled "Definitely liked." Participants like Candidate B $($ mean $=6.33)$ significantly more than Candidate A $($ mean $=4.14)(\mathrm{t}=6.96, \mathrm{p}<0.01)$, which reinforces the notion that Candidate A possesses fewer accompanying desirable traits compared to Candidate B. Finally, participants answer salience checks and demographic questions.

\subsection{Results}

To test our central hypothesis, we examine whether hiring decisions differ between type of organization. Because PO fit assessments generally occur before the hiring decision in the real world, we also explore whether PO fit assessments are affected by organization type. We form a composite measure of PO fit by averaging the responses to the nine questions shown in Appendix C. An averaging approach is appropriate because the PO fit questions collectively measure one unidimensional construct. Cronbach's (1951) alpha is 0.96 and there is a single eigenvalue greater than one (it is 6.77).

Panel A of Figure 2 provides the mean continuous PO fit assessment and the dichotomous PO fit assessment in the for-profit public company condition (recall that this is the condition in which the organization faces comparatively high pressure to manage earnings). The

\footnotetext{
However, indirect questioning may reduce the effect of social desirability bias (Fisher 1993). Thus, we phrase the
} candidate selection question using indirect questioning. 
mean assessment is 31.53 and is significantly below the midpoint of the 100-point response scale $(t=6.04, p<0.01)$. This indicates that Candidate $A$ is considered to be the better fit. Likewise, when the PO fit assessment is dichotomized at the scale's midpoint, 85.71 percent of participants believe that Candidate $\mathrm{A}$ is the better fit, while only 14.29 percent believe that Candidate $\mathrm{B}$ is the better fit. The percentages are significantly different from the midpoint $\left(\chi^{2}=28.57, p<0.01\right)$, indicating a strong belief that Candidate $\mathrm{A}$ is the better fit in the context of a for-profit public company that faces pressure to manage earnings.

Panel B provides the mean continuous choice and dichotomous choice in the for-profit public company condition. The mean continuous choice is 23.93 and is significantly below the midpoint of the response scale $(\mathrm{t}=7.09, \mathrm{p}<0.01)$. This indicates that Candidate $\mathrm{A}$ is considered most likely to be hired. When the continuous choice is dichotomized at the scale's midpoint, we find that 87.50 percent of the participants believe that Candidate $\mathrm{A}$ is most likely to be hired and only 12.50 percent believe that Candidate B is most likely to be hired. These percentages are significantly different from the midpoint $\left(\chi^{2}=31.50, \mathrm{p}<0.01\right)$, indicating a strong belief that Candidate A will be hired. These results, when considered along with the PO fit results, indicate that Candidate A will likely be hired over Candidate B because Candidate A is considered a better fit for the senior accounting manager position in the organization that faces greater pressure to manage earnings.

Panel $\mathrm{C}$ of Figure 2 provides the mean continuous PO fit assessment and the dichotomous PO fit assessment in the non-profit foundation condition (recall that this is the condition in which the organization faces comparatively lower pressure to manage earnings). The mean fit assessment is 69.63 , which is significantly above the midpoint of the 100-point response scale ( $\mathrm{t}$ $=6.64, \mathrm{p}<0.01)$. This indicates that Candidate B is considered to be the better fit. Similarly, 
when the fit assessment is dichotomized at the scale's midpoint, 87.72 percent of participants believe that Candidate B is the better fit, while only 12.28 percent believe that Candidate A is the better fit. The percentages are significantly different from the midpoint $\left(\chi^{2}=32.44, p<0.01\right)$, indicating a strong belief that Candidate B is the better fit in the context of a non-profit foundation that faces comparatively low pressure to manage earnings.

Panel D provides the mean continuous choice and dichotomous choice in the non-profit foundation condition. The mean of the continuous choice is 75.91 and is significantly above the midpoint of the response scale $(t=7.01, p<0.01)$. This indicates that Candidate $B$ is most likely to be hired. When the continuous choice is dichotomized at the midpoint, 85.96 percent believe that Candidate B is the most likely to be hired, while only 14.04 percent believe that Candidate A is the most likely to be hired. The percentages are significantly different from the midpoint $\left(\chi^{2}=\right.$ 29.49, $\mathrm{p}<0.01$ ), indicating a strong belief that Candidate B will be hired. These results, when considered along with the PO fit results, indicate participants' belief that Candidate B will be hired over Candidate A because Candidate B is considered to be a better fit for the senior accounting manager position in the context of an organization that faces comparatively low pressure to manage earnings.

To test whether the organization type significantly impacts the hiring decision and fit assessments, we estimate the effect of ORG_TYPE on HIRE and FIT, where HIRE is participants' response to the job candidate selection question (responses are provided on a 100point sliding scale with the left endpoint labeled "Definitely Candidate A" and the right endpoint labeled "Definitely Candidate B"), FIT is participants' mean response to the nine PO fit questions shown in Appendix C (responses are provided on a 100-point sliding scale, with the left endpoint labeled "Definitely Candidate A" and the right endpoint labeled "Definitely 
Candidate B"), and ORG_TYPE is manipulated between subjects as either a for-profit public company (coded as 1) or a non-profit foundation (coded as 0 ). The coefficient on ORG_TYPE is expected to be negative.

Panel A of Table 2 provides a correlation matrix of the study variables. Panel B of Table 2 reports regression results, which show a significant effect of organization type on hiring decision $\left(\beta_{1}=-51.98, \mathrm{t}=-9.97, \mathrm{p}<0.01\right)$ as well as fit assessment $\left(\beta_{2}=-38.10, \mathrm{t}=-8.94, \mathrm{p}<\right.$ 0.01). ${ }^{20}$ The results indicate that Candidate $\mathrm{A}$ is more likely to be hired and assessed as a better fit at the for-profit public company than at the non-profit foundation. Taken together, our results are quite decisive. In the for-profit public company condition, participants overwhelmingly believe that Candidate A is the best fit for the position and that he/she will ultimately be hired. In the non-profit foundation condition, participants overwhelmingly believe that Candidate B is the best fit for the position and that he/she will ultimately be hired. The only thing that differs between the two conditions is the type of organization and its related financial objectives. Thus, we find support for our research hypothesis that organizations facing pressure to manage earnings tend to favor accounting job candidates with dark personalities.

Although the results of Experiment 1 are consistent with the idea that candidates with dark personality traits are more likely to be hired for positions that require pushing ethical boundaries to manage earnings, the experiment has some limitations. For example, there may be other reasons to prefer Candidate A at a for-profit company but Candidate B at a non-profit organization. While we believe this context provided a rich environment and interesting context for testing our hypothesis, we conduct a second experiment to hold the type of organization constant while manipulating only the pressure to manage earnings.

\footnotetext{
${ }^{20}$ All hypothesized statistical tests, as indicated in our main tables, are reported with one-tailed p-values.
} 


\section{Experiment 2}

\subsection{Purpose}

Experiment 2 seeks to extend Experiment 1 by holding the organization constant and varying pressure to manage earnings by manipulating the purpose for which the financial statements will be used (firm valuation versus owner monitoring) in a for-profit private company setting. Prior research argues that managers of initial public offering firms face considerable pressure to manage earnings upwards in order to maximize proceeds from the sale of shares (e.g., Friedlan 1994, Teoh et al. 1998). Thus, we expect that when the financial statements are used by valuation professionals to determine the selling price of the company's stock, Candidate A will be preferred over Candidate B because Candidate A is viewed as having a proclivity to prepare financial statements that report higher earnings. We expect the preference for Candidate A will be greatly reduced when the financial statements are used to monitor and control operations. In fact, Candidate B may be preferred due to his/her apparent proclivity to provide transparent and representationally faithful financial information. If candidates with dark personalities are more likely to be hired in positions with higher earnings management pressure in this alternative setting, we would have greater confidence that our central hypothesis is descriptively valid.

\subsection{Participant recruitment}

We obtained participants through Qualtrics, which recruits participants nationwide. We required participants to meet screening criteria related to age ( 25 or older), education (bachelor's degree or higher), accounting coursework (at least one accounting course), finance coursework (at least one finance course), and work experience (five years or more). Qualtrics recommends including a memory question, which enables identifying participants who have not carefully attended to the task and denying payment to those participants. The data provided by Qualtrics 
excludes those participants who miss the memory question. Our arrangement with Qualtrics called for 110 participants at a total cost of $\$ 625 .^{21}$

\subsection{Demographics}

Demographic information is reported in Panel A of Table 3. Participants' mean age is 51.15 years and their mean work experience is 28.30 years. Participants indicate that they are familiar with the duties of chief accounting officers (mean $=7.50)$ and with evaluating job candidates for purposes of making hiring decisions/recommendations $($ mean $=7.93) .{ }^{22}$ The mean number of accounting and finance courses taken by participants is 5.92 and 4.45 , respectively. Approximately 59 percent of participants are male.

\subsection{Instrument}

Participants learn that the owner of a private company is currently seeking to hire a chief accounting officer to oversee the company's accounting operations, including the preparation of financial statements. Participants are randomly assigned to one of two experimental conditions.

In the firm valuation condition, we state the following:

The owner of the company will sell the company in the near-term. The primary use of the financial statements, as prepared by the newly-hired chief accounting officer, will be to value the company. The purpose of valuing the company is to determine its selling price. Outside valuation professionals will determine the selling price using information reported in the financial statements. Higher reported earnings and better financial performance reported in the financial statements will increase the amount for which the owner can sell the company, thereby enhancing the owner's wealth.

In the owner monitoring condition, we state the following:

The owner of the company will maintain ownership long-term. The primary use of the financial statements, as prepared by the newly-hired chief accounting officer, will be to monitor company operations. The purpose of monitoring company operations is to identify inefficiencies and correct them quickly. By effectively monitoring operations, the owner will conserve scarce resources that would otherwise be wasted, thereby enhancing the owner's wealth. The ability of the owner to effectively monitor the company's operations depends on

\footnotetext{
${ }^{21}$ The concept of a response rate is not relevant in this experiment. We sought 110 participants and once that threshold number of participants was met, the experiment was closed.

${ }^{22}$ Responses are provided on a 10-point scale with higher responses indicating greater familiarity.
} 
the financial statements being informative about what is actually happening within the company.

By varying the purpose for which the financial statements will be used, we manipulate the extent to which participants feel that the company faces pressure to manage earnings. The instrument is silent about the company's financial objectives and does not ask participants to assess PO fit.

Participants are informed that a large pool of applicants for the chief accounting officer position has been considered, and two candidates have been selected as finalists. Participants then receive information about the two job candidates, which is identical to the information presented to participants in Experiment 1. Participants then respond to the candidate selection question, which states "Based on your assessment of the two job candidates and the chief accounting officer position specifically described in this study, which candidate do you believe that the owner would most likely hire to fill the position?" Participants respond on a 100-point scale. The left endpoint is labeled "Definitely Candidate A" and the right endpoint is labeled “Definitely Candidate B.” We also elicit participants' ratings of the likeability of the two candidates on a 10-point scale with the left endpoint labeled "Definitely disliked" and the right endpoint labeled "Definitely liked." Participants rate Candidate B $($ mean $=6.41)$ and Candidate A $($ mean $=6.17)$ equally likeable $(t=0.78, p=0.44)$. Lastly, participants answer salience checks, a manipulation check, and demographic questions. ${ }^{23}$

\subsection{Results}

To test whether there is a difference in hiring decisions across the two experimental conditions, we estimate the effect of PURP on HIRE, where HIRE is participants' response to the candidate selection question as discussed in connection with the instrument above, and PURP is the purpose for which the financial statements will be used, which is manipulated between

\footnotetext{
${ }^{23}$ We have one manipulation check, and 97 percent of our participants respond to it correctly.
} 
subjects and coded as 1 for the valuation condition and coded as 0 for the monitoring condition. The coefficient on PURP is expected to be negative.

Panel A of Table 3 provides a correlation matrix of the study variables. Panel B of Table 3 reports the regression results, which show a significant effect of financial statement purpose on hiring decision $\left(\beta_{3}=-20.80, t=-3.07, p<0.01\right)$. In untabulated analyses, we find that participants' mean hiring decision in the valuation condition is 29.86 , which is significantly below the midpoint of the scale $(\mathrm{t}=-4.54, \mathrm{p}<0.01)$. This indicates that participants in the valuation condition strongly prefer hiring Candidate A. Participants' mean hiring decision in the monitoring condition is 50.66, which does not differ from the midpoint of the scale $(t=0.03, p=$ 0.97). This indicates that participants in the monitoring condition are largely indifferent between the two candidates. These findings are consistent with those of Experiment 1, which suggests that job candidates with dark personalities are favored when organizations face pressure to manage earnings.

While our results thus far indicate that earnings management pressure increases the likelihood that candidates with dark personalities will be hired and assessed as a better fit, further exploration of the recruiting process seems warranted. In particular, for many high-level positions, professional recruiters provide an initial screening mechanism for potential candidates. Further, professional recruiters should possess significant experience assessing candidate fit and personality, as well as matching candidates to jobs based on job descriptions. We conduct a third experiment using professional recruiters in order to ascertain whether candidates with dark personalities are more likely to be referred early on in the hiring process, which would further increase the matching between dark personalities and companies facing earnings management pressure. 


\section{Experiment 3}

\subsection{Purpose}

This experiment examines the fit assessments and client referral decisions of experienced executive recruitment professionals who screen job candidates before those candidates interview with company officials. In this experiment, we manipulate between subjects the personality traits of a job candidate for a high-level accounting position. After evaluating either Candidate A or Candidate B, participants assess PO fit and indicate how likely the candidate is to be referred to a client for consideration for a senior accounting manager position.

\subsection{Participant Recruitment}

We sought participation from executive recruitment professionals who have experience placing job candidates in accounting and/or finance positions. To identify such participants, we examined the online biographical sketches of executive recruitment professionals. We invited 561 executive recruitment professionals to participate in our experiment via email (39 emails were returned as undeliverable) and sent a follow-up email approximately one week later. The experiment was administered via Qualtrics. To increase the response rate, we offered each respondent a $\$ 10$ gift card for participation. A total of 41 executive recruitment professionals participated in this experiment, resulting in a response rate of 7.85 percent.

\subsection{Demographics}

Demographic information is reported in Panel A of Table 4. Participants' mean age is 45.03 years and their mean work experience is 23.21 years. Participants indicate that they are familiar with the duties of senior accounting managers (mean $=7.47$ on a 10 -point scale with higher responses indicating greater familiarity). The mean number of executive searches and accounting/finance searches in which our participants have been involved is 518.99 and 400.57 , 
respectively. The mean number of accounting and finance courses taken by participants is 5.91 and 4.13, respectively. Approximately 64 percent of participants are male.

\subsection{Instrument}

Participants consider a situation faced by a hypothetical executive recruitment consultant who works for an executive recruitment firm. Participants are informed that a public company client of the recruitment firm is seeking to fill a vacant senior accounting manager position. Participants then learn about the client's financial objectives, which employees of the client are committed to achieving (these objectives are identical to those in Instrument Validation Study B and Experiment 1). Participants are then informed that the consultant is making a decision about whether to refer a particular candidate to the client to interview for the senior accounting manager position. The candidate being considered is either Candidate A or Candidate B but not both (see Appendix A). Thus, we manipulate the personality profile of the job candidate between subjects at two levels, but hold all other aspects of the job candidate summary constant. ${ }^{24}$ Participants are randomly assigned to experimental conditions.

The materials explain that the candidate has the technical competence and qualifications for the senior accounting manager position, but that the client relies on the consultant to ensure that job candidates who are referred for an interview are a good fit for the position. We develop five accounting-related PO fit questions tailored to our context (see Appendix D). Participants respond to these accounting fit questions on a 100-point sliding scale, with the left endpoint labeled "Definitely not" and the right endpoint labeled "Definitely yes." After responding to the

\footnotetext{
${ }^{24}$ The job candidate profiles are amalgamations of different personality traits as shown in Appendix A. On the surface, one might speculate that a single trait could be a dominant consideration when making an employee selection or referral decision. To address this issue, we ask participants in Experiment 3 whether they considered the candidate's overall personality profile or they considered only a specific personality trait. Only four of the 41 participants indicated that they focused on a specific personality trait.
} 
fit questions, participants respond to the client referral question, which states "Based on your evaluation of the candidate and the information about the client, how likely is the consultant to refer the candidate to the client to interview for the senior accounting manager position?" Participants respond on the same 100-point sliding scale as the fit questions. Participants then rate the likeability of the job candidate on a 10-point scale with the left endpoint labeled "Definitely disliked" and the right endpoint labeled "Definitely liked." The likeability results indicate that participants like Candidate B $($ mean $=5.39)$ significantly more than Candidate A $($ mean $=3.43)(t=2.49, \mathrm{p}=0.02)$, which suggests that participants view Candidate A's personality as generally less desirable. Lastly, participants answer salience checks, a manipulation check, and demographic questions. ${ }^{25,26}$

\subsection{Results}

Our central hypothesis predicts that when clients face pressure to manage earnings, job candidates who possess more dark personality traits are more likely to be referred to clients than are job candidates who possess fewer dark traits. PO fit is an important consideration to executive recruitment professionals when making client referral decisions. We form a composite measure of accounting-related PO fit by averaging the responses to the fit questions shown in Appendix D. An averaging approach is appropriate because the fit questions collectively

\footnotetext{
${ }^{25}$ We have a single manipulation check question that has three parts, each of which focuses on a different dimension of the job candidate's personality. Approximately 85 percent of our participants characterize the job candidate's personality in a manner consistent with the intended message of the personality profile.

${ }^{26}$ The two job candidates are both perceived to be qualified for a senior accounting manager position, but they are very different in terms of their personalities (see Section 3 ). At the same time, both of the candidates are reasonable representations of job candidates who might pursue a senior accounting manager position. One of the postexperimental questions asks participants in Experiment 3 to indicate whether someone like the job candidate described would actually apply for a senior accounting manager position. Participants respond on a 10-point scale with the left endpoint labeled "Definitely not" and the right endpoint labeled "Definitely yes." The mean response for Candidate A is 8.29 and the mean response for Candidate B is 8.81. Thus, while we have created job candidates whose personality profiles seem very different, they are not extreme in terms of the types of individuals who might pursue a senior accounting manager position.
} 
measure one unidimensional construct. Cronbach's (1951) alpha is 0.92 and there is a single eigenvalue greater than one (it is 3.85).

To test our hypothesis in the context of professional recruiter referrals, we examine the relationship between participants' client referral decisions and the job candidate being considered. Thus, we estimate the effect of CAND on REF and AFIT, where REF is participants' response to the client referral question and AFIT is calculated as participants' average response to the five accounting fit questions shown in Appendix D. CAND is manipulated between subjects, coded as 1 for participants who evaluated Candidate A and coded as 0 for participants who evaluated Candidate B. The coefficient on CAND is expected to be positive.

Panel A of Table 4 provides a correlation matrix of the study variables, and Panel B reports the regression results. The coefficient on CAND is positive and significant when considering the referral decision, $\operatorname{REF}\left(\beta_{4}=17.85, \mathrm{t}=1.84, \mathrm{p}<0.05\right)$. The coefficient on CAND is also positive and significant when considering the accounting fit assessment, AFIT $\left(\beta_{5}=\right.$ $46.51, \mathrm{t}=8.41, \mathrm{p}<0.01)$. These results indicate that Candidate $\mathrm{A}$, relative to Candidate $\mathrm{B}$, is perceived as a better fit and is more likely to be referred to a position with high earnings management pressure, which provides support for our central hypothesis. The results also suggest that screening for candidates with dark personalities could happen very early in the hiring process, even at the initial recruiting phase.

\section{Conclusion}

This paper provides provocative evidence about the types of individuals who are hired into positions of power and authority in the accounting function of organizations. The results of our studies support our research hypothesis that, in the presence of earnings management pressure, job candidates who possess more dark personality traits (i.e., Candidate A) are more 
likely to be hired than candidates who possess fewer dark personality traits (i.e., Candidate B). We also find that executive recruitment professionals are more likely to screen out candidates without dark personalities before they are considered by prospective employers. Our results arise despite the fact that (1) Candidate $\mathrm{A}$ is considered to be a significantly worse manager than Candidate B, (2) Candidate A is perceived to be more likely to engage in fraud than Candidate B, (3) Candidate A is perceived to be less likely to maintain high ethical standards in the face of adversity than Candidate B, and (4) Candidate A is viewed by many as generally less likeable than Candidate B. We therefore conclude that the perceived willingness to push ethical boundaries, as signaled by dark personality traits, represents an important dimension of candidate fit and hiring potential when organizations face pressure to manage earnings.

The results of this study should be considered in light of potential limitations. First, we do not examine naturally occurring data (e.g., employment files). Future research could provide further evidence on this issue if data becomes available. However, privacy issues and legal concerns may generally preclude such an approach. Second, participants in this study made a hypothetical decision without all the information that would normally be available when making hiring and referral decisions in practice. Future research could examine how additional information (e.g., information about the candidate pool and the position) might amplify or dilute the impact of candidate personality traits. Third, the design of some of our studies inform participants about the firm's financial objectives and also have participants assess PO fit, which could create demand bias. However, this design choice mimics actual features of the real-world and thus enhances the generalizability of our results. Fourth, we only expose participants to two job candidates rather than a large portfolio of job applicants. In the real-world, there are often numerous job candidates which must be evaluated. However, in order to make our experiments 
tractable and fairly brief, we elected to have participants evaluate two job candidates only. Fifth, real-world hiring (and promotion) decisions often involve complex trade-offs which are not easily incorporated into experimental settings. Our settings are simplified in that they (1) involve limited information, (2) preclude complex deliberations, and (3) reflect a stylized trade-off between managerial competence and earnings management. Lastly, some of our studies rely on the voluntary participation of experienced professionals, and response rates in those studies are somewhat modest and sample sizes are limited. It is possible that the inferences and conclusions of our research may be sensitive to these features. However, as discussed by Nelson and Skinner (2013), this concern is reduced when interpreting directional treatment effects, which is the case in our studies. Furthermore, we conducted multiple experiments to test our hypothesis and this multiple experiment approach allows us to demonstrate the robustness and generalizability of our findings with different participant pools and different operationalizations of the constructs of interest (Asay et al. 2019).

Our results expand upon prior research suggesting that the negative consequences of hiring managers with dark personalities (e.g., Duchon and Drake 2009, Amernic and Craig 2010, Boddy 2011, Rijsenbilt and Commandeur 2013, Olsen et al. 2014, Ham et al. 2017, Buchholz et al. 2019, Van Scotter and Roglio 2020) may stem from those same managers possessing perceived positive traits such as confidence, creativity, and strong leadership skills (e.g., Caldwell and O'Reilly 1982, Raskin et al. 1991, Brunell et al. 2008, Babiak et al. 2010, Goncalo et al. 2010, Nevicka et al. 2011, Zettler and Solga 2013, Ong et al. 2016). Our experiments demonstrate that managers with dark personalities may be matched to organizations facing earnings management pressure not because of their perceived accompanying desirable traits, but because of their perceived willingness to push ethical boundaries. 
Our findings also raise questions about the effectiveness of promulgating new accounting rules and regulations as a way to reign in earnings management. The SEC has a long history of enacting regulations designed to combat earnings management and perceived accounting abuses (e.g., Staff Accounting Bulletins No. 99, 100, and 101), but the employee selection process in organizations may result in those organizations populating high-level accounting positions with individuals who have dark personality traits that are associated with a predisposition to manage earnings. Under such circumstances, new rules and regulations may have only a modest effect on earnings management. By focusing on employee selection, we have identified one of the potential root causes of earnings management. When asking why earnings management persists over time, we believe one answer to this question resides in the types of people who are recruited and selected by, and retained in, organizations.

Future research in this area could investigate whether interventions in the recruiting and hiring process could help reduce the tendency to favor candidates with dark personalities when earnings management pressure is high. For example, because prior research has shown negative workplace environment outcomes produced by managers with dark personalities (Duchon and Drake 2009, Boddy 2011), involving a wider array of current employees (and future subordinates) in the hiring process may help place increased emphasis on candidate shortcomings along those dimensions. Research examining whether and how candidates with dark personalities are attracted to apply to accounting positions in the first place also seems warranted, as the hiring process involves many sequential steps from candidate job search and application submission to screening, referral, interviews, and finally the ultimate hiring decision. Future studies could examine the biases and structural deficiencies in each of these steps that lead to the recruitment of managers with dark personalities. 


\section{APPENDIX A}

\section{Job Candidate Personality Profiles}

\begin{tabular}{|c|c|}
\hline More dark personality traits (Candidate A) & Fewer dark personality traits (Candidate B) \\
\hline High moral disengagement & Low moral disengagement \\
\hline $\begin{array}{l}\text { 1. Is results-oriented and believes that the end results are more } \\
\text { important than the process by which one pursues those } \\
\text { results. }\end{array}$ & $\begin{array}{l}\text { Is process-oriented and believes that the process by } \\
\text { which one pursues results is more important than the } \\
\text { results themselves. }\end{array}$ \\
\hline $\begin{array}{l}\text { 2. Believes that rules must be flexible enough to be adapted to } \\
\text { different situations and will rewrite the rules if necessary to } \\
\text { achieve goals. }\end{array}$ & $\begin{array}{l}\text { 2. Believes that rules are established purposefully, } \\
\text { should not be circumvented to achieve goals, and } \\
\text { should be changed only after significant deliberation. }\end{array}$ \\
\hline $\begin{array}{l}\text { 3. Quickly assesses the norms of the organization and looks to } \\
\text { those norms to determine what behavior is acceptable. }\end{array}$ & $\begin{array}{l}\text { 3. Has rigid beliefs about what constitutes acceptable } \\
\text { behavior and rarely deviates from those beliefs. }\end{array}$ \\
\hline High Machiavellianism & Low Machiavellianism \\
\hline $\begin{array}{l}\text { 4. Believes that subordinates should only be pri } \\
\text { specific information needed to do their jobs e }\end{array}$ & $\begin{array}{l}\text { 4. Belie } \\
\text { availa }\end{array}$ \\
\hline High narcissism & Low narcissism \\
\hline Responds well to flattery and compliments. & iments. \\
\hline $\begin{array}{l}\text { center of attention when in the presence of } \\
\text { le. }\end{array}$ & $\begin{array}{l}\text { in the spotlight when in the } \\
\text { eople. }\end{array}$ \\
\hline w idealist, high relativist & Ethical or \\
\hline $\begin{array}{l}\text { 7. Makes decisions by comparing the benefits and costs of } \\
\text { each decision, and accepts that some decisions might } \\
\text { negatively impact others in some way. }\end{array}$ & $\begin{array}{l}\text { 7. Avoids decisions that might negatively impact } \\
\text { others, even if that harm is insignificant. }\end{array}$ \\
\hline $\begin{array}{l}\text { 8. Believes that ideas about what constitutes moral or immoral } \\
\text { behavior vary from person to person and from situation to } \\
\text { situation. }\end{array}$ & $\begin{array}{l}\text { 8. } \mathrm{Be} \\
\text { im } \\
\text { per }\end{array}$ \\
\hline High self- & Low self \\
\hline $\begin{array}{l}\text { 9. Can change behaviors and opinions to suit different people } \\
\text { and different situations. }\end{array}$ & $\begin{array}{l}\text { inions to suit } \\
\text { uations. }\end{array}$ \\
\hline Locus of co & Locus of ce \\
\hline $\begin{array}{l}\text { 10. Believes that leadership achievements require the ability to } \\
\text { please those in positions of power. }\end{array}$ & $\begin{array}{l}\text { 10. Believes that leadership achievements are chiefly } \\
\text { due to being in the right place at the right time. }\end{array}$ \\
\hline High ability to rationalize behavior & Low ability to rationalize behavior \\
\hline $\begin{array}{l}\text { 11. Will take actions that feel right at the moment even if those } \\
\text { actions seem inconsistent with values. }\end{array}$ & 11. Will take actions only after deliberation to avoid \\
\hline 12. Can find justifications for actions after the fact. & 12. Prefers to avoid having to justify actions after the fact \\
\hline
\end{tabular}

Headings are not included in the actual instruments completed by participants in our studies and experiments (they are shown here for informational purposes only). See Section 3 and Appendix B for a discussion of the job candidate personality profiles and their development. 


\section{APPENDIX B}

\section{Summary of the Development of the Job Candidate Personality Profiles}

The starting point in the development of the job candidate personality profiles in Appendix A was to identify dark personality traits that plausibly signal an individual's predisposition to manage earnings. Although there are numerous validated personality scales that meet this criterion, six particular scales stood out as being suitable for our purpose. In addition, we develop one scale ourselves (a scale designed to measure an individual's ability to rationalize questionable behavior). To determine whether the items comprising the scales signal information about an individual's predisposition to manage earnings, we conduct a survey using 102 participants from Amazon's Mechanical Turk platform (results not tabulated).

The survey defines "earnings management" using a composite, non-technical definition from the accounting literature (see Instrument Validation Study A for our definition of earnings management). The survey then expresses the items comprising the scales as a series of independent statements about the beliefs of an individual. After each statement, participants rate how likely an individual who holds a particular belief is to manage earnings. Participants respond on an 11-point scale ranging from -5 to +5 , with the left endpoint labeled "Unlikely to manage earnings," the right endpoint labeled "Likely to manage earnings," and the midpoint labeled "Neutral." Each of the personality scales is discussed below.

Moral disengagement (Shu, Gino, and Bazerman 2011). Moral disengagement occurs when individuals try to persuade themselves that their own questionable behavior is morally permissible. The mean of the moral disengagement items are significantly above zero (mean $=1.61, \mathrm{t}=5.56, \mathrm{p}<0.01)$, which indicates that individuals who morally disengage are perceived to be predisposed to manage earnings.

Machiavellianism and narcissism (Paulhus and Jones 2011). Machiavellianism is characterized by manipulation and exploitation of others, and narcissism is characterized by self-focus and an undue sense of selfimportance. The means of Machiavellianism items (mean $=1.19, \mathrm{t}=5.22, \mathrm{p}<0.01)$ and the narcissism items (mean $=1.04, \mathrm{t}=6.29, \mathrm{p}<0.01$ ) are both significantly above zero, which indicates that individuals who measure high on these personality traits are perceived to be predisposed to manage earnings.

Ethical orientation (Forsyth 1980). Ethical orientation describes an individual's moral philosophies. Idealism and relativism are two dimensions of ethical orientation. The mean of the idealist items are significantly below zero (mean $=-0.75, \mathrm{t}=-2.71, \mathrm{p}<0.01$ ), indicating that idealists are not perceived to be predisposed to manage earnings. The mean of the relativist items are significantly above zero (mean $=1.25, \mathrm{t}=5.44, \mathrm{p}<0.01$ ), indicating that relativists are perceived to be predisposed to manage earnings.

Self-monitoring (Snyder and Gangestad 1986). Self-monitoring is a personality trait characterized by concern about managing one's behavior to accommodate social situations. The mean of the self-monitoring items is significantly above zero (mean $=0.99, \mathrm{t}=5.18, \mathrm{p}<0.01$ ), indicating that high self-monitors are perceived to be predisposed to manage earnings.

Locus of control (Levenson 1973). Locus of control refers to the extent to which an individual believes $\mathrm{he} / \mathrm{she}$ can control events in their lives. The means of the internal locus of control items (mean $=1.72, \mathrm{t}=9.02, \mathrm{p}$ $<0.01$ ) and the powerful others locus of control items (mean $=0.82, \mathrm{t}=3.71, \mathrm{p}<0.01$ ) are both significantly above zero, which indicates that individuals who score high on these dimensions are perceived to be predisposed to manage earnings. The mean of the chance locus of control items is significantly below zero (mean $=-0.73, \mathrm{t}=\mathrm{-}$ $3.59, \mathrm{p}<0.01$ ), which indicates that individuals who score high on this dimension are not perceived to be predisposed to manage earnings.

Ability to rationalize behavior. Earnings management is often considered to be questionable behavior, and some individuals can readily rationalize such behavior. The mean of the ability to rationalize behavior items is significantly above zero (mean $=1.27, \mathrm{t}=4.39, \mathrm{p}<0.01$ ), indicating that those individuals who can readily rationalize questionable behavior are perceived to be predisposed to manage earnings. 


\section{APPENDIX C}

\section{PO Fit Questions}

1. Which candidate's attitude is most compatible with the culture of the Company (Foundation)?

2. Which candidate's value system is most compatible with the culture of the Company (Foundation)?

3. Which candidate's belief system is most compatible with the culture of the Company (Foundation)?

4. Which candidate's personality is most compatible with the culture of the Company (Foundation)?

5. Which candidate has priorities that are most similar to the priorities of the Company (Foundation)?

6. Which candidate is most likely to clash with the culture of the Company (Foundation)?

7. Which candidate's behaviors, beliefs, and values will be valued most by the Company (Foundation)?

8. Which candidate will find the senior accounting manager position most personally and professionally rewarding?

9. Which candidate is most likely to have to do something they do not like in order to meet the Company's (Foundation's) expectations?

See Section 4 for a discussion of the PO fit questions. Participants in Experiment 1 respond to these questions on a 100-point sliding scale, with the left endpoint labeled "Definitely Candidate A" and the right endpoint labeled "Definitely Candidate B." Responses to questions 6 and 9 are reverse coded for analysis. 


\section{APPENDIX D \\ Accounting-Related PO Fit Questions}

1. Candidate A (B) will make accounting decisions to bolster reported profits.

2. Candidate A (B) will make accounting decisions to achieve desired profit goals.

3. Candidate A (B) will find a way to report the smoothest possible earnings to keep borrowing costs low.

4. Candidate A (B) will push boundaries to meet analysts' earnings forecasts for the company.

5. Candidate A (B) will portray financial performance in the most favorable light possible.

See Section 6 for a discussion of the accounting-related PO fit questions. The organizational behavior and human resources literature does not provide direct guidance in the formulation of the accounting-related PO fit questions. When formulating these questions, we drew upon our knowledge of the intersection between PO fit and accounting. Participants in Experiment 3 respond to these questions on a 100-point sliding scale, with the left endpoint labeled "Definitely not" and the right endpoint labeled "Definitely yes." 


\section{References}

Albrecht, W., Albrecht, C., Albrecht, C., and Zimbleman, M. (2012). Fraud Examination. 4th edition. Mason, OH: Thompson-Southwestern.

Alchian, A. (1950). Uncertainty, evolution, and economic theory. The Journal of Political Economy 58 (3), 211-221.

Allen, D. G., Moffitt, K. R., and Weeks, K. P. (2005). Turnover intentions and voluntary turnover: The moderating roles of self-monitoring, locus of control, proactive personality, and risk aversion. Journal of Applied Psychology 90 (5), 980-990.

Amernic, J., and Craig, R. (2010). Accounting as a facilitator of extreme narcissism. Journal of Business Ethics 96, 79-93.

Asay, S., Guggenmos, R., Kadous, K., Koonce, L., and Libby, R. (2019). Theory testing and process evidence in accounting experiments. Working paper, University of Iowa.

Ashbaugh-Skaife, H., Collins, D., Kinney, W., and LaFond, R. (2008). The effect of SOX internal control deficiencies and their remediation on accrual quality. The Accounting Review 83 (1), 217-250.

Aziz, N., May, K., and Crotts, J.C. (2002). Relations of Machiavellian behavior with sales performance of stockbrokers. Psychological Reports 90, 451-460.

Babiak, P. (1995). When psychopaths go to work: A case study of an industrial psychopath. Applied Psychology 44 (2), 171-188.

Baez, B. (2013). Personality tests in employment selection: Use with caution. Cornell HR Review. Website. http://www.cornellhrreview.org/personality-tests-in-employmentselection-use-with-caution/ 
Bartov, E., Givoly, D., and Hayn, C. (2002). The rewards to meeting or beating earnings expectations. Journal of Accounting and Economics 33 (2), 173-204.

Belschak, F. D., Muhammad, R. S., and Den Hartog, D. N. (2018). Birds of a feather can butt heads: When machiavellian employees work with machiavellian leaders. Journal of Business Ethics 151, 613-626.

Blair, C. A., Hoffman, B. J., and Helland, K. R. (2008). Narcissism in organizations: A multisource appraisal reflects different perspectives. Human Performance 21, 254-276.

Blickle, G., Schlegel, A., Fassbender, P., and Klein, U. (2006). Some personality correlates of business white-collar crime. Applied Psychology 55 (2), 220-233.

Boddy, C. (2011). Corporate psychopaths, bullying, and unfair supervision in the workplace. Journal of Business Ethics 100, 367-379.

Boddy, C. (2017). Psychopathic leadership: A case study of a corporate psychopathic CEO. Journal of Business Ethics 145, 141-156.

Boddy, C., Miles, D., Sanyal, C., and Hartog, M. (2015). Extreme managers, extreme workplaces: Capitalism, organizations, and corporate psychopaths. Organization 22 (4), $530-551$.

Brazel, J., Lucianetti, L., and Schaefer, T. (2020). Reporting concerns about earnings quality: an examination of corporate managers. Journal of Business Ethics, forthcoming.

Brickley, J., Smith, C., and Zimmerman, J. (2009). Managerial Economics and Organizational Architecture. 5th edition. New York, NY: McGraw-Hill.

Brown, L., and Caylor, M. (2005). A temporal analysis of quarterly earnings thresholds: Propensities and valuation consequences. The Accounting Review 80 (2), 423-440. 
Brunell, A., Gentry, W., Campbell, W., Hoffman, B., Kuhnert, K., and DeMarree, K. (2008). Leader emergence: the case of the narcissistic leader. Personality and Social Psychology Bulletin 34 (12), 1663-1676.

Bruns W., and Merchant, K. (1990). The dangerous morality of managing earnings. Management Accounting 72 (2), 22-25.

Buchholz, F., Lopatta, K., and Mass, K. (2019). The deliberate engagement of narcissistic CEOs in earnings management. Journal of Business Ethics, forthcoming.

Cable, D., and Judge, T. (1997). Interviewers' perceptions of person-organization fit and organizational selection decisions. Journal of Applied Psychology 82 (4), 546-561.

Caldwell, D., and O'Reilly, III, C. (1982). Responses to failure: The effects of choice and responsibility on impression management. Academy of Management Journal 25 (1), 121136.

Carcello, J., Hermanson, D., and Ye, Z. (2011). Corporate governance research in accounting and auditing: Insights, practice implications, and future research directions. Auditing: $A$ Journal of Practice \& Theory 30 (3), 1-31.

Chatman, J. (1989). Improving interactional organizational research: A model of personorganization fit. Academy of Management Review 14 (3), 333-349.

Chen, Q. (2016). Director monitoring of expense misreporting in non-profit organizations: The effects of expense disclosure transparency, donor evaluation focus and organization performance. Contemporary Accounting Research 33 (4), 1601-1624.

Chung, J., and Hsu, S. (2017). The effect of cognitive moral development on honesty in managerial reporting. Journal of Business Ethics 145, 563-575. 
Cohen, D., Dey, A., and Lys, T. (2008). Real and accrual-based earnings management in the preand post-Sarbanes-Oxley periods. The Accounting Review 83 (3), 757-787.

Cohen, J., Ding, Y., Lesage, C., and Stolowy, H. (2010). Corporate fraud and managers' behavior: evidence from the press. Journal of Business Ethics 95, 271-315.

Cohen, J., Krishnamoorthy, G., and Wright, A. (2010). Corporate governance in the postSarbanes-Oxley era: Auditors' experiences. Contemporary Accounting Research 27 (3), 751-786.

Cronbach, L. (1951). Coefficient alpha and the internal structure of tests. Psychometrika 16 (3), 297-334.

Das, S., Kim, K., and Patro, S. (2011). An analysis of managerial use and market consequences of earnings management and expectation management. The Accounting Review 86 (6), 1935-1967.

Dechow, P., and Skinner, D. (2000). Earnings management: Reconciling the views of accounting academics, practitioners, and regulators. Accounting Horizons 14 (2), 235-250.

Dechow, P., Sloan, R., and Sweeney, A. (1996). Causes and consequences of earnings manipulation: An analysis of firms subject to enforcement actions by the SEC. Contemporary Accounting Research 13 (1), 1-36.

Deluga, R. J. (1997). Relationship among American presidential charismatic leadership, narcissism, and rated performance. The Leadership Quarterly 8, 49-65.

Den Hartog, D., and Belschak, F. D. (2012). Work engagement and machiavellianism in the ethical leadership process. Journal of Business Ethics 107, 35-47. 
Desai, H., Hogan, C., and Wilkins, M. (2006). The reputational penalty for aggressive accounting: Earnings restatements and management turnover. The Accounting Review 81 (1): 83-112.

DeZoort, T., Hermanson, D., and Houston, R. (2008). Audit committee member support for proposed audit adjustments: Pre-SOX versus post-SOX judgments. Auditing: A Journal of Practice \& Theory 27 (1), 85-104.

Dichev, I., Graham, J., Harvey, C., and Rajgopal, S. (2013). Earnings quality: Evidence from the field. Journal of Accounting and Economics 56 (2-3), 1-33.

Duchon, D., and Drake, B. (2009). Organizational narcissism and virtuous behavior. Journal of Business Ethics 85, 301-308.

Edwards, J. (2008). Person-environment fit in organizations: An assessment of theoretical progress. The Academy of Management Annals 2 (1), 167-230.

Eisenbeiss, S. A., and Brodbeck, F. (2014). Ethical and unethical leadership: A cross-cultural and cross-sectoral analysis. Journal of Business Ethics 122, 343-359.

Elias, R. (2002). Determinants of earnings management ethics among accountants. Journal of Business Ethics 40 (1), 33-45.

Feng, M., Ge, W., Luo, S., and Shevlin, T. (2011). Why do CFOs become involved in material accounting manipulations? Journal of Accounting and Economics 51 (1), 21-36.

Fisher, R. (1993). Social desirability bias and the validity of indirect questioning. Journal of Consumer Research 20 (2), 303-315.

Friedlan, J. (1994). Accounting choices of issuers of initial public offerings. Contemporary Accounting Research 11 (1), 1-31. 
Fuller, J., and Jensen, M. (2002). Just say no to Wall Street: Putting a stop to the earnings game. Journal of Applied Corporate Finance 14 (4), 41-46.

Furnham, A., Hyde, G., and Trickey G. (2012). Bright aspects to dark side traits: Dark side traits associated with work success. Personality and Individual Differences 52 (8), 908-913.

Gkorezis, P., Petridou, E., and Krouklidou, T. (2015). The detrimental effect of machiavellian leadership on employees' emotional exhaustion: Organizational cynicism as a mediator. Europe's Journal of Psychology 11 (4), 619-631.

Gowthorpe, C., and Amat, O. (2005). Creative accounting: some ethical issues of macro- and micro-manipulation. Journal of Business Ethics 57, 55-64.

Graham, J., Harvey, C. and Rajgopal, S. (2005). The economic implications of corporate financial reporting. Journal of Accounting and Economics 40 (1), 3-73.

Greenfield, A., Norman, C., and Wier, B. (2008). The effect of ethical orientation and professional commitment on earnings management behavior. Journal of Business Ethics $83(3), 419-434$.

Ham, C., Lang, M., Seybert, N., and Wang, S. (2017). CFO narcissism and financial reporting quality. Journal of Accounting Research 55 (5),1089-1135.

Healy, P., and Wahlen, J. (1999). A review of the earnings management literature and its implications for standard setting. Accounting Horizons 13 (4), 365-383.

Hogan, R., Raskin, R., \& Fazzini, D. (1990). The dark side of charisma. In K. E. Clark, \& M. B. Clark (Eds.), Measures of leadership (pp. 343-354). West Orange, NJ: Leadership Library of America.

Iliev, P. (2010). The effect of SOX Section 404: Costs, earnings quality, and stock prices. The Journal of Finance 65 (3), 1163-1196. 
Jain, P., Kim, J., and Rezaee, Z. (2008). The Sarbanes-Oxley Act of 2002 and market liquidity. The Financial Review 43 (3), 361-382.

Jawahar, I. M. (2001). Attitudes, self-monitoring, and appraisal behaviors. Journal of Applied Psychology 86 (5), 875-883.

Jensen, M. (2001). Corporate budgeting is broken—Let's fix it. Harvard Business Review 79 (10), 94-101.

Johnson, E., Kuhn, J., Apostolou, B., and Hassell, J. (2013). Auditor perceptions of client narcissism as a fraud attitude risk factor. Auditing: A Journal of Practice \& Theory 32 (1), 203-219.

Judge, T., LePine, J., and Rich, B. (2006). Loving yourself abundantly: Relationship of the Narcissistic personality to self- and other perceptions of workplace deviance, leadership, and task and contextual performance. Journal of Applied Psychology 91 (4), 762-776.

Kalshoven, K., De Hoogh, A, and Den Hartog, D. (2011). Ethical leader behavior and the big five factors of personality. Journal of Business Ethics 100, 349-366.

Kelly, K., and Murphy, P. (2019). Reducing accounting aggressiveness with general ethical norms and decision structure. Journal of Business Ethics, forthcoming.

Kilduff, M., and Day, D. V. (1994). Do chameleons get ahead? The effects of self-monitoring on managerial careers. Academy of Management Journal 37 (4), 1047-1060.

Krell, E. (2005). Personality counts: Personality assessments are being used in new ways through the employee life cycle. HR Magazine 50 (11), 46-53.

Kristof, A. (1996). Person - organization fit: An integrative review of its conceptualizations, measurement, and implications. Personnel Psychology 49 (1), 1-49.

Levitt, A. (1998). The numbers game. CPA Journal 68 (12), 14-18. 
Linck, J., Netter, J., and Yang, T. (2009). The effects and unintended consequences of the Sarbanes-Oxley Act on the supply and demand for directors. Review of Financial Studies 22 (8): $3287-3328$.

Lobo, G., and Zhou, J. (2006). Did conservatism in financial reporting increase after the Sarbanes-Oxley Act? Initial evidence. Accounting Horizons 20 (1), 57-73.

Maccoby, M. (2007). Narcissistic leaders: Who succeeds and who fails. Boston, MA: Harvard Business School Press.

Majors, T. (2016). The interaction of communicating measurement uncertainty and the dark triad on managers' reporting decisions. The Accounting Review 91, 973-992.

Mehra, A., M. Kilduff, and Brass, D. J. (2001). The social networks of high and low selfmonitors: Implications for workplace performance. Administrative Science Quarterly 46, $121-146$.

Merchant, K., and Rockness, J. (1994). The ethics of managing earnings: An empirical investigation. Journal of Accounting and Public Policy 13 (1), 79-94.

Murphy, P. (2012). Attitude, Machiavellianism and the rationalization of misreporting. Accounting, Organizations and Society 37 (4), 242-259.

O'Connor, J. A., Mumford, M. D., Clifton, T. C., Gessner, T. L., and Connelly, M. S. (1995). Charismatic leaders and destructiveness: An historiometric study. The Leadership Quarterly 6, 529-555.

O’Reilly, C., Doerr, B., Caldwell, D., and Chatman, J. (2014). Narcissistic CEOs and executive compensation. The Leadership Quarterly 25 (2), 218-231.

Olsen, K., Dworkis, K., and Young, M. (2014). CEO narcissism and accounting: a picture of profits. Journal of Management Accounting Research 26 (2), 243-267. 
Parfet, W. (2000). Accounting subjectivity and earnings management: A preparer perspective. Accounting Horizons 14 (4), 481-488.

Paunonen, S., Lonnqvist, J.-E., Verkasalo, M., and Leikas, S. (2006). Narcissism and emergent leadership in military cadets. The Leadership Quarterly 17 (5), 475-486.

Rijsenbilt, A., and Commandeur, H. (2013). Narcissus enters the courtroom: CEO narcissism and fraud. Journal of Business Ethics 117, 413-429.

Rosenthal, S., and Pittinsky, T. (2006). Narcissistic leadership. The Leadership Quarterly 17 (6), 617-633.

Rosenzweig, K. and Fischer, M. (1994). Is managing earnings ethically acceptable? Management Accounting 75 (3), 31-34.

Rynes, S., and Gerhart, B. (1990). Interviewer assessments of applicant "fit": An exploratory investigation. Personnel Psychology 43 (1), 13-35.

Schipper, K. (1989). Commentary on earnings management. Accounting Horizons 3 (4), 91-102.

Schneider, B. (1987). The people make the place. Personnel Psychology 40 (3), 437-453.

Schrand, C., and Zechman, S. (2012). Executive overconfidence and the slippery slope to financial misreporting. Journal of Accounting and Economics 53 (1-2), 311-329.

Shultz, J. S. (1993). Situational and dispositional predictions of performance: A test of the hypothesized Machiavellianism x structure interaction among salespersons. Journal of Applied Social Psychology 23, 478-498.

Seybert, N. (2010). R\&D capitalization and reputation-driven real earnings management. The Accounting Review 85 (2), 671-693.

Schnure, K. (2010). Narcissism levels and ratings of executive leadership potential. Annual Conference of the Society for Industrial and Organizational Psychology, Atlanta, GA. 
Spangler, W., Gupta, A., Kim, D. H., and Nazarian, S. (2012). Developing and validating historiometric measures of leader individual differences by computerized content analysis of documents. The Leadership Quarterly 23 (6), 1152-1172.

Spurk, D., Keller, A. C., and Hirschi, A. (2016). Do bad guys get ahead or fall behind? Relationships of the dark triad of personality with objective and subjective career success. Social Psychological and Personality Science 7 (2), 113-121.

Stabile, S. (2002). Use of personality tests as a hiring tool: Is the benefit worth the cost? University of Pennsylvania Journal of Labor and Employment Law 4 (2), 279-313.

Suh, I., Sweeney, J., Linke, K., and Wall, J. (2020). Boiling the frog slowly: the immersion of csuite financial executives into fraud. Journal of Business Ethics 162, 645-673.

Teoh, S., Wong, T. and Rao, G. (1998). Are accruals during initial public offerings opportunistic? Review of Accounting Studies 3 (1-2), 175-208.

Van Scotter, J.R., Roglio, K.D. (2020). CEO bright and dark personality: effects on ethical misconduct. Journal of Business Ethics 164, 451-475.

Wagner, S., and Dittmar, L. (2006). The unexpected benefits of Sarbanes-Oxley. Harvard Business Review 84 (4), 133-140.

Watts, R., and Zimmerman, J. (1986). Positive Accounting Theory. Englewood Cliffs, NJ: Prentice Hall.

Wille, B., De Fruyt, F., and de Clercq, B. (2013). Expanding and reconceptualizing aberrant personality at work: validity of five-factor model aberrant personality tendencies to predict career outcomes. Personnel Psychology 66, 173-223. 
Yetman, M., and Yetman, R. (2012). The effects of governance on the accuracy of charitable expenses reported by nonprofit organizations. Contemporary Accounting Research 29 (3), 738-767.

Yetman, M., and Yetman, R. (2013). Do donors discount low-quality accounting information? The Accounting Review 88 (3), 1041-1067.

Zerbe, W., and Paulhus, D. (1987). Socially desirable responding in organizational behavior: A reconception. Academy of Management Review 12 (2), 250-264.

Zettler, I, and Solga, M. (2013). Not enough of a 'dark' trait? Linking Machiavellianism to job performance. European Journal of Personality 27 (6), 545-554.

Zimmerman, J. (2003). Accounting for Decision Making and Control. 4th edition. New York, NY: McGraw-Hill.

Zona, F., Minoja, M., and Coda, V. (2013). Antecedents of corporate scandals: CEOs' personal traits, stakeholders' cohesion, managerial fraud, and imbalanced corporate strategy. Journal of Business Ethics 113, 265-283. 
FIGURE 1

Graph of Results for Instrument Validation Study B (n=99)

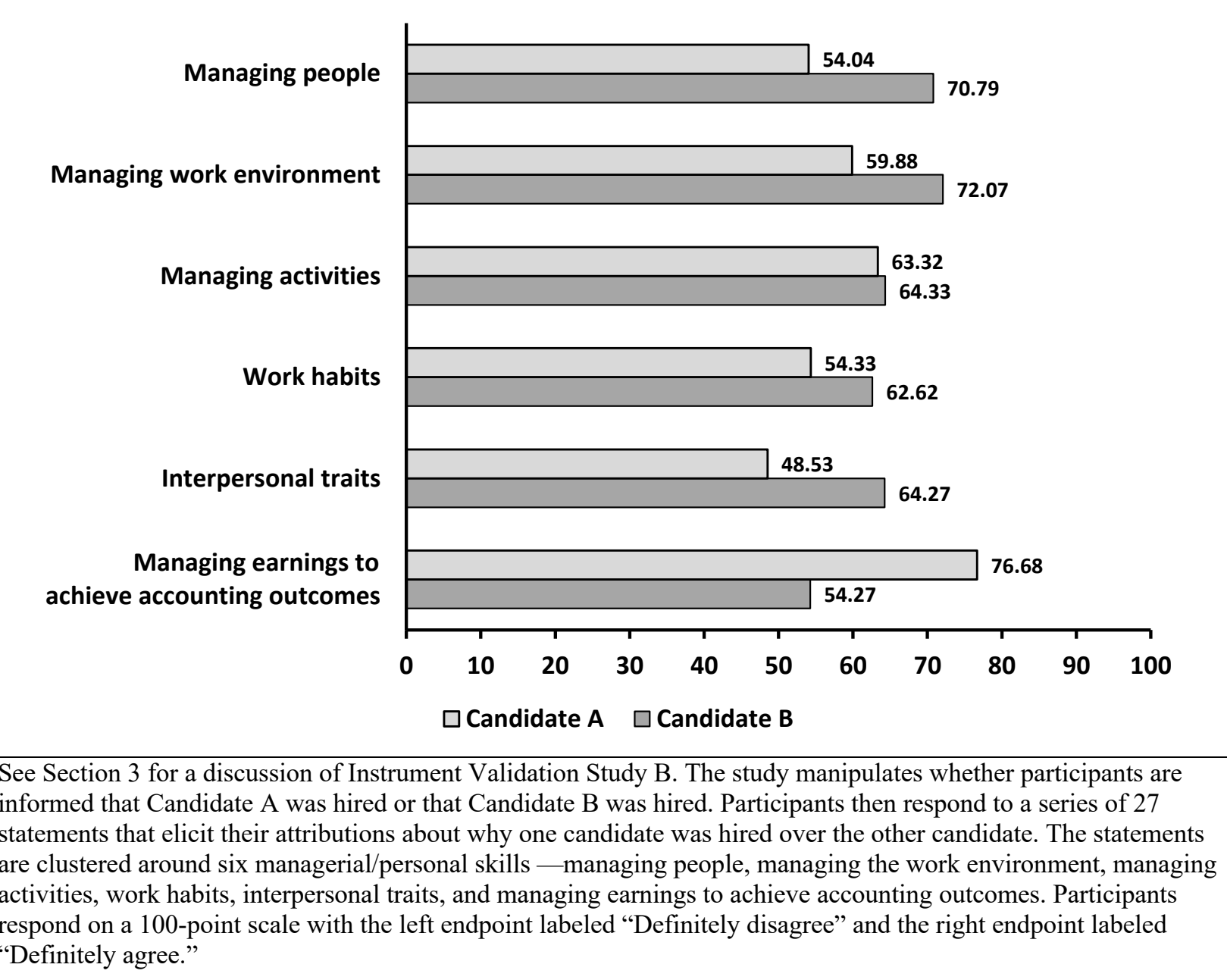




\section{FIGURE 2}

\section{Graph of Results for Experiment 1}

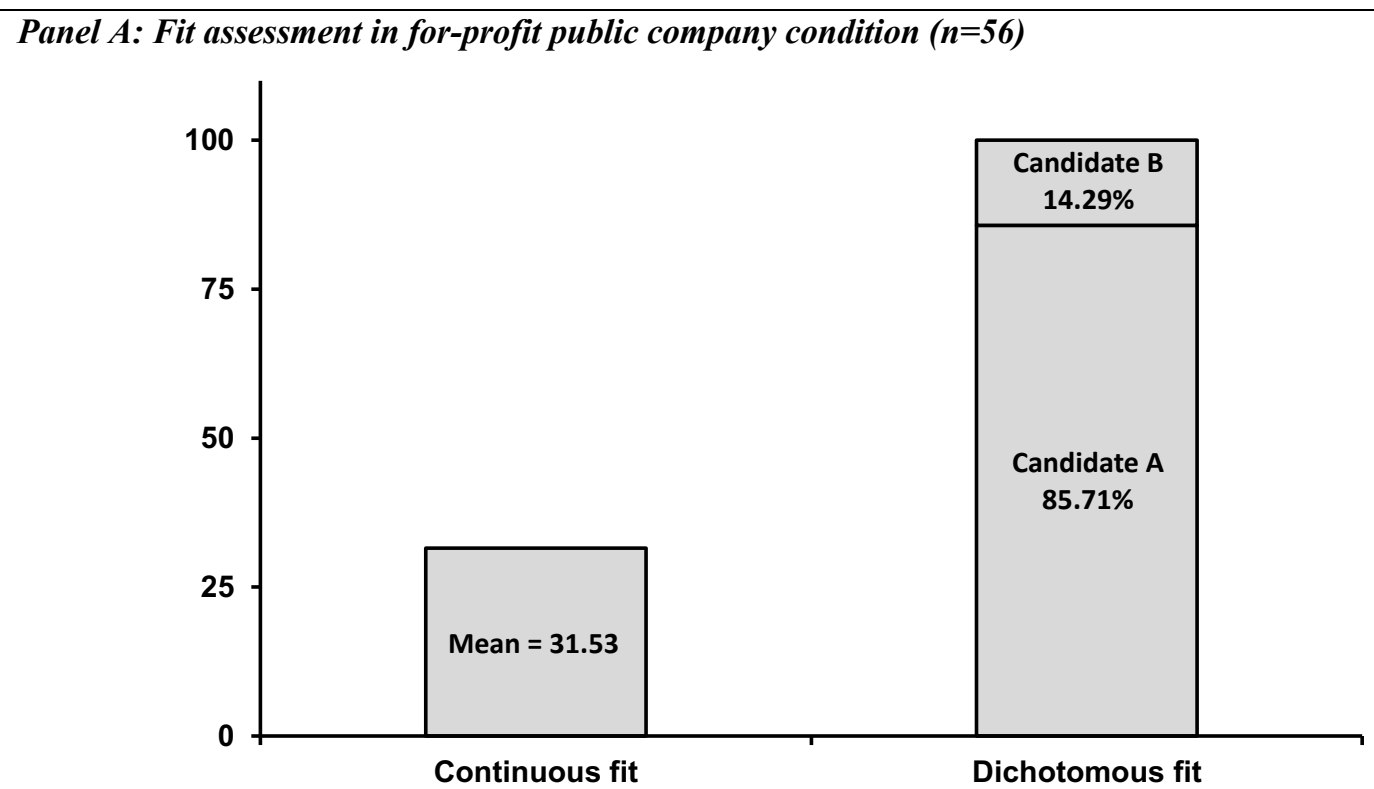

Panel B: Choice between job candidates in for-profit public company condition (n=56)

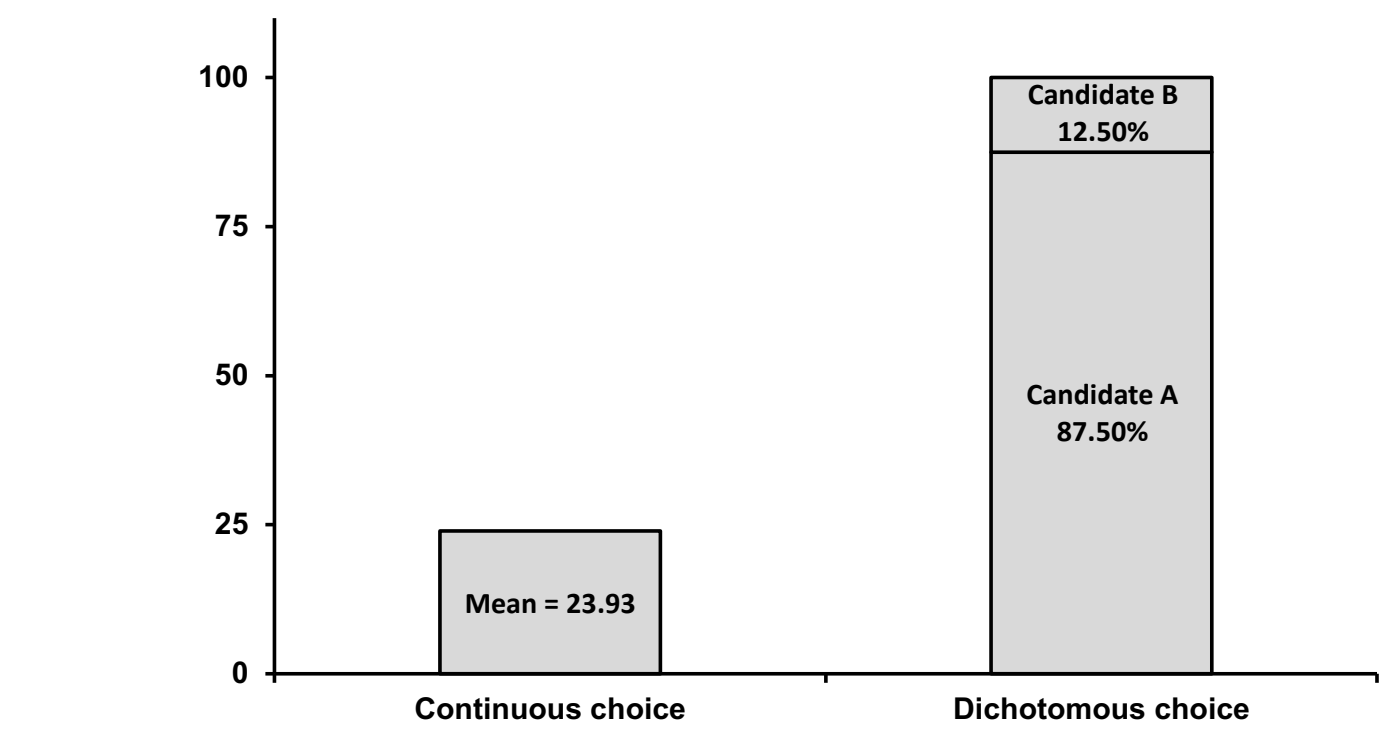

Continued 
FIGURE 2 (Continued)

\section{Graph of Results for Experiment 1}

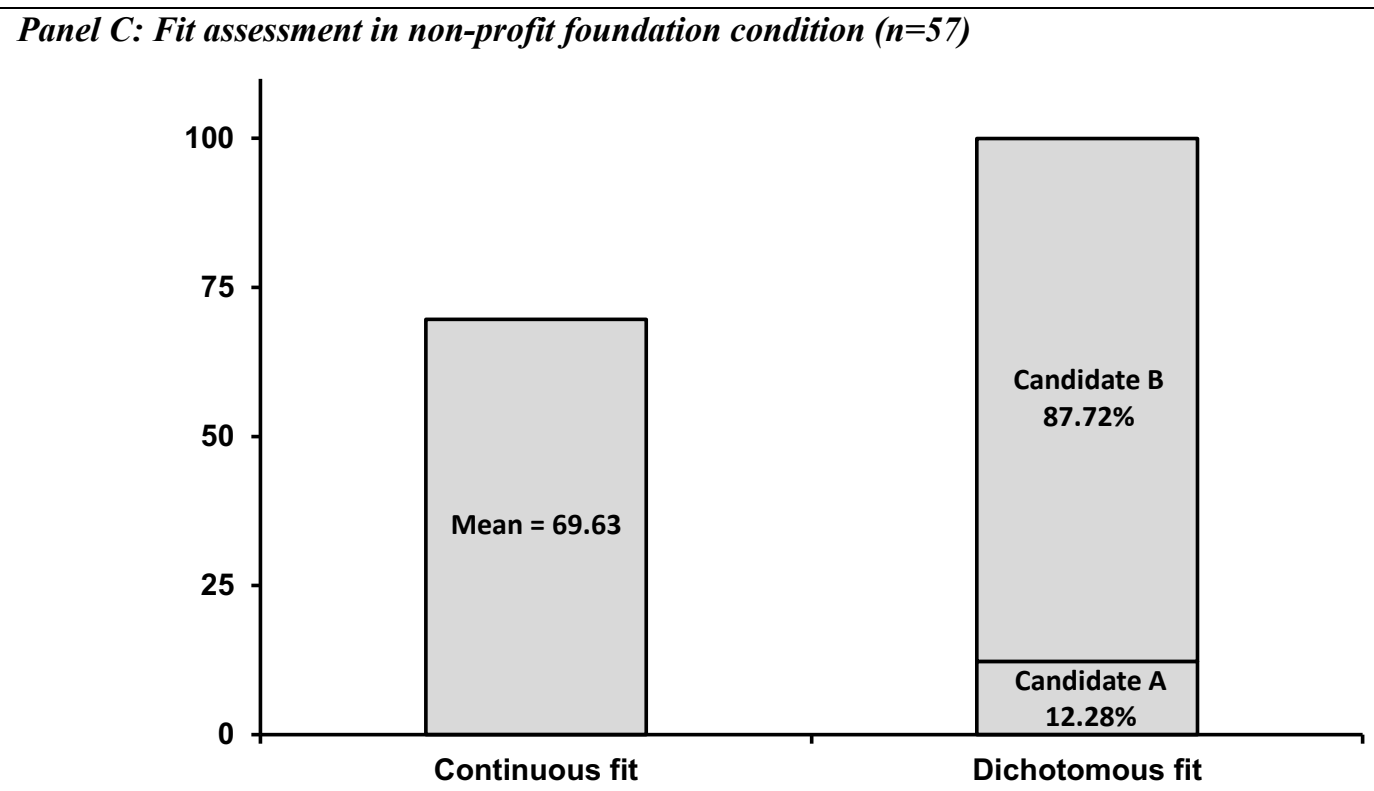

Panel D: Choice between job candidates in non-profit foundation condition ( $n=57)$

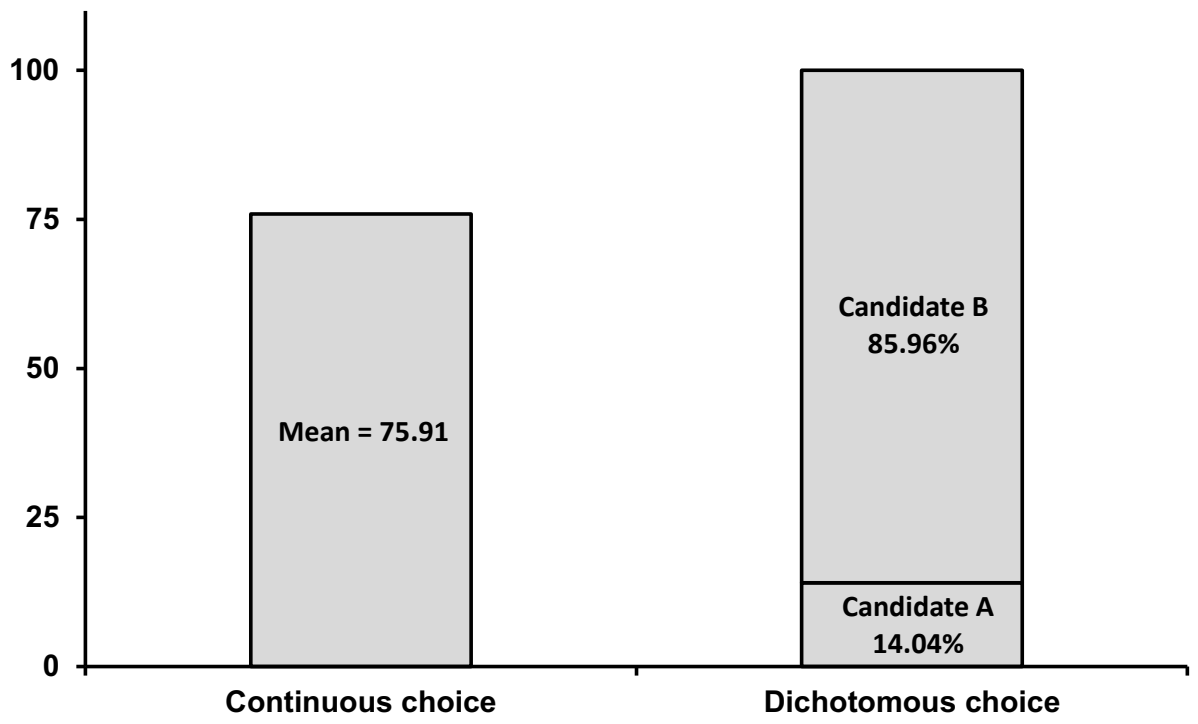

See Section 4 for a discussion of Experiment 1. Appendix A contains the personality descriptors for the job candidates. In Panels A and C, the fit assessment is the mean of the nine PO fit questions shown in Appendix C. In Panels B and D, the choice between job candidate question states "Based on your assessment of the candidates and the information about the Company (Foundation), which candidate do you believe the Company (Foundation) will most likely hire to fill the senior accounting manager position?" In Panels B and D, participants respond on a 100point sliding scale, with the left endpoint labeled "Definitely Candidate A" and the right endpoint labeled "Definitely Candidate B." The dichotomous response is coded as 0 if the response is below the mid-point of the scale (a preference for Candidate A) and 1 if the response is above the mid-point of the scale (a preference for Candidate B). 


\section{TABLE 1}

\section{Results for Instrument Validation Study A (n=59)}

\begin{tabular}{|c|c|c|c|}
\hline Question & Mean & t-stat. & p \\
\hline Which candidate is MOST likely to initiate efforts to manage earnings? & 10.88 & 15.93 & $<0.01$ \\
\hline $\begin{array}{l}\text { Which candidate is LEAST likely to go along with existing efforts to manage } \\
\text { earnings? }\end{array}$ & 81.76 & 9.38 & $<0.01$ \\
\hline Which candidate is MOST uncomfortable managing earnings? & 80.93 & 7.82 & $<0.01$ \\
\hline Which candidate is MOST likely to encourage others to manage earnings? & 15.83 & 13.49 & $<0.01$ \\
\hline $\begin{array}{l}\text { 5. Which candidate is MOST susceptible to pressure from others to manage } \\
\text { earnings? }\end{array}$ & 15.36 & 12.30 & $<0.01$ \\
\hline Which candidate is MOST likely to steer others away from managing earnings? & 80.49 & 9.14 & $<0.01$ \\
\hline $\begin{array}{l}\text { Which candidate MOST likely believes that the positive consequences of } \\
\text { earnings management justify engaging in that behavior? }\end{array}$ & 12.25 & 15.53 & $<0.01$ \\
\hline $\begin{array}{l}\text { 8. Which candidate is MOST likely to participate in types of earnings } \\
\text { management that would be considered fraudulent? }\end{array}$ & 14.53 & 13.87 & $<0.01$ \\
\hline $\begin{array}{l}\text { 9. Which candidate is MOST likely to follow a company code of ethics that } \\
\text { prohibits earnings management? }\end{array}$ & 92.05 & 23.07 & $<0.01$ \\
\hline $\begin{array}{l}\text { 10. Which candidate is MOST likely to set an exemplary standard of ethical } \\
\text { behavior? }\end{array}$ & 87.07 & 16.14 & $<0.01$ \\
\hline $\begin{array}{l}\text { 11. Which candidate is MOST likely to engage in a series of seemingly harmless } \\
\text { accounting decisions that lead to serious accounting infractions, including } \\
\text { fraud? }\end{array}$ & 15.35 & 14.86 & $<0.01$ \\
\hline 12. Which candidate holds them self to the HIGHEST ethical standards? & 89.19 & 18.55 & $<0.01$ \\
\hline $\begin{array}{l}\text { 13. Which candidate is MOST likely to relax their standards of ethical behavior in } \\
\text { the face of professional gain? }\end{array}$ & 10.52 & 26.28 & $<0.01$ \\
\hline $\begin{array}{l}\text { 14. Which candidate is LEAST likely to relax their standards of ethical behavior in } \\
\text { the face of professional hardship? }\end{array}$ & 84.49 & 10.09 & $<0.01$ \\
\hline
\end{tabular}

See Section 3 for a discussion of Instrument Validation Study A. Appendix A contains the personality descriptors for the job candidates. Participants respond to the questions on a 100-point sliding scale, with the left endpoint labeled "Definitely Candidate A" and the right endpoint labeled "Definitely Candidate B." The t-statistics test whether the mean response differs from the midpoint of the scale. 
TABLE 2

\section{Results for Experiment 1}

Panel A: Descriptive Statistics and Correlations for Study Variables

\begin{tabular}{|c|c|c|c|c|c|c|c|c|c|c|c|c|c|c|c|}
\hline Variables & Mean & SD & $\mathbf{N}$ & 1 & 2 & 3 & 4 & 5 & 6 & 7 & 8 & 9 & 10 & 11 & 12 \\
\hline \multicolumn{16}{|l|}{ 1. ORG_TYPE } \\
\hline 2. FIT & 50.75 & 29.57 & 113 & $-0.65 * *$ & & & & & & & & & & & \\
\hline 3. HIRE & 50.15 & 37.98 & 113 & $-0.69 * *$ & $0.93 * *$ & & & & & & & & & & \\
\hline 4. Age in years & 50.71 & 9.54 & 94 & 0.05 & 0.02 & 0.00 & & & & & & & & & \\
\hline $\begin{array}{l}5 . \text { Work experience in } \\
\text { years }\end{array}$ & 27.74 & 9.82 & 107 & 0.08 & 0.00 & 0.00 & $0.86^{* *}$ & & & & & & & & \\
\hline $\begin{array}{l}\text { 6. Familiarity with } \\
\text { duties of accounting } \\
\text { managers }\end{array}$ & 8.83 & 1.56 & 106 & 0.12 & -0.02 & -0.01 & $-0.27 * *$ & $-0.23 * *$ & & & & & & & \\
\hline $\begin{array}{l}\text { 7. Familiarity with } \\
\text { evaluating job } \\
\text { candidates }\end{array}$ & 9.04 & 1.11 & 107 & 0.08 & 0.04 & 0.03 & -0.09 & -0.02 & $0.38 * *$ & & & & & & \\
\hline $\begin{array}{l}\text { 8. Employee headcount } \\
\text { at current employer }\end{array}$ & $5,902.50$ & $13,002.67$ & 106 & -0.01 & 0.08 & 0.06 & -0.08 & -0.06 & 0.00 & 0.06 & & & & & \\
\hline $\begin{array}{l}\text { 9. Percent with } \\
\text { experience in a public } \\
\text { company }\end{array}$ & 67.30 & 47.14 & 104 & 0.10 & -0.05 & -0.04 & 0.09 & 0.14 & $0.21 *$ & $0.23 *$ & $0.21 *$ & & & & \\
\hline $\begin{array}{l}\text { 10. Percent with } \\
\text { experience in a non- } \\
\text { profit organization }\end{array}$ & 60.38 & 49.14 & 106 & -0.03 & 0.13 & 0.10 & 0.01 & -0.07 & $0.21 *$ & -0.08 & 0.02 & 0.03 & & & \\
\hline $\begin{array}{l}11 . \text { Number of } \\
\text { accounting courses } \\
\text { taken }\end{array}$ & 11.65 & 11.84 & 104 & -0.08 & 0.13 & 0.10 & -0.17 & -0.13 & $0.23 * *$ & 0.09 & 0.01 & $0.23 * *$ & 0.11 & & \\
\hline $\begin{array}{l}\text { 12. Number of finance } \\
\text { courses taken }\end{array}$ & 5.76 & 7.22 & 105 & 0.03 & 0.10 & 0.14 & -0.13 & -0.08 & 0.15 & 0.13 & 0.06 & $0.19 *$ & -0.02 & $0.71 * *$ & \\
\hline 13. Percent male & 53.47 & 50.13 & 101 & 0.03 & -0.01 & -0.03 & 0.06 & 0.11 & -0.09 & 0.09 & $0.21 *$ & $0.30 * *$ & -0.13 & 0.08 & $0.27 * *$ \\
\hline
\end{tabular}


Panel B: Regression Results $(n=113)$

\begin{tabular}{|c|c|c|c|c|}
\hline \multirow{2}{*}{$\begin{array}{c}\text { Dependent } \\
\text { Variable }\end{array}$} & \multicolumn{2}{|c|}{ Independent Variable } & \multirow{2}{*}{$\begin{array}{c}\text { Model } \\
\text { F-statistic }\end{array}$} & \multirow{2}{*}{$\begin{array}{c}\text { Adjusted } \\
\mathbf{R}^{2}(\%) \\
\end{array}$} \\
\hline & Intercept & ORG_TYPE & & \\
\hline HIRE & 75.91 & $\beta_{1}=-51.98$ & 99.46 & 46.78 \\
\hline t-statistic & 20.69 & $-9.97 * *$ & & \\
\hline FIT & 69.63 & $\beta_{2}=-38.10$ & 79.93 & 41.34 \\
\hline t-statistic & 23.21 & $-8.94 * *$ & & \\
\hline \multicolumn{5}{|c|}{$\begin{array}{l}\text { See Section } 4 \text { for a discussion of Experiment 1. ORG_TYPE is manipulated between subjects as either a for-profit } \\
\text { public company (coded as } 1 \text { ) or a non-profit foundation (coded as 0); FIT is participants' mean response to the nine } \\
\text { PO fit questions shown in Appendix C (responses are provided on a 100-point sliding scale, with the left endpoint } \\
\text { labeled "Definitely Candidate A" and the right endpoint labeled "Definitely Candidate B"); HIRE is participants' } \\
\text { response to the job candidate selection question (responses are on a 100-point sliding scale with the left endpoint } \\
\text { labeled "Definitely Candidate A" and the right endpoint labeled "Definitely Candidate B"). Some participants did } \\
\text { not answer all demographic questions, so the number of observations for each demographic question varies. } \\
\text { Responses to the questions about familiarity with the duties of accounting managers and familiarity with evaluating } \\
\text { job candidates are provided on } 10 \text {-point scales with higher responses indicating greater familiarity. ** and * denote } \\
\text { statistical significance at } p<0.01 \text { and } p<0.05 \text {, respectively. P-values are one-tailed where we have directional } \\
\text { predictions. }\end{array}$} \\
\hline
\end{tabular}


TABLE 3

\section{Results for Experiment 2}

Panel A: Descriptive Statistics and Correlations for Study Variables

\begin{tabular}{|c|c|c|c|c|c|c|c|c|c|c|c|}
\hline Variables & Mean & SD & $\mathbf{N}$ & 1 & 2 & 3 & 4 & 5 & 6 & 7 & 8 \\
\hline 1. PURP & 0.52 & 0.50 & 110 & & & & & & & & \\
\hline 2. HIRE & 39.88 & 36.84 & 110 & $-0.28 * *$ & & & & & & & \\
\hline 3. Age in years & 51.15 & 15.25 & 110 & 0.01 & 0.11 & & & & & & \\
\hline $\begin{array}{l}\text { 4. Work experience in } \\
\text { years }\end{array}$ & 28.30 & 34.23 & 110 & 0.07 & 0.17 & $0.36 * *$ & & & & & \\
\hline $\begin{array}{l}\text { 5. Familiarity with duties } \\
\text { of chief accounting officer }\end{array}$ & 7.50 & 1.67 & 110 & -0.05 & 0.02 & 0.02 & 0.18 & & & & \\
\hline $\begin{array}{l}\text { 6. Familiarity with } \\
\text { evaluating job candidates }\end{array}$ & 7.93 & 2.05 & 110 & 0.03 & -0.08 & 0.00 & 0.13 & $0.37 * *$ & & & \\
\hline $\begin{array}{l}\text { 7. Number of accounting } \\
\text { courses taken }\end{array}$ & 5.92 & 5.21 & 109 & -0.13 & 0.10 & 0.03 & 0.20 & 0.10 & -0.02 & & \\
\hline $\begin{array}{l}\text { 8. Number of finance } \\
\text { courses taken }\end{array}$ & 4.45 & 4.35 & 110 & -0.12 & 0.10 & -0.09 & -0.07 & 0.04 & 0.09 & $0.34 * *$ & \\
\hline 9. Percent male & 59.09 & 49.39 & 110 & -0.10 & 0.11 & 0.14 & $0.18^{*}$ & 0.08 & 0.08 & -0.02 & 0.07 \\
\hline
\end{tabular}


Panel B: Regression Results $(\mathbf{n}=\mathbf{1 1 0})$

\begin{tabular}{|c|c|c|c|c|}
\hline \multirow{2}{*}{$\begin{array}{l}\text { Dependent } \\
\text { Variable }\end{array}$} & \multicolumn{2}{|c|}{ Independent Variable } & \multirow{2}{*}{$\begin{array}{c}\text { Model } \\
\text { F-statistic }\end{array}$} & \multirow{2}{*}{$\begin{array}{c}\text { Adjusted } \\
\mathbf{R}^{2}(\%)\end{array}$} \\
\hline & Intercept & PURP & & \\
\hline HIRE & 50.66 & $\beta_{3}=-20.80$ & 9.43 & 7.18 \\
\hline t-statistic & 10.39 & -3.07 & & \\
\hline
\end{tabular}

See Section 5 for a discussion of Experiment 2. PURP is the purpose for which the financial statements are used, which is manipulated between subjects as valuation (coded as 1) or monitoring (coded as 0 ); HIRE is participants' hiring decision (responses are provided on a 100-point sliding scale with the left endpoint labeled "Definitely Candidate A" and the right endpoint labeled "Definitely Candidate B"). One participant did not respond to the question about the number of accounting courses taken. Responses to the questions about familiarity with the duties of chief accounting officer and familiarity with evaluating job candidates are provided on 10-point scales with higher responses indicating greater familiarity. $* *$ and $*$ denote statistical significance at $\mathrm{p}<0.01$ and $\mathrm{p}<0.05$, respectively. P-values are one-tailed where we have directional predictions. 
TABLE 4

\section{Results for Experiment 3}

Panel A: Descriptive Statistics and Correlations for Study Variables

\begin{tabular}{|c|c|c|c|c|c|c|c|c|c|c|c|c|c|}
\hline Variables & Mean & SD & $\mathbf{N}$ & 1 & 2 & 3 & 4 & 5 & 6 & 7 & 8 & 9 & 10 \\
\hline 1. CAND & 4.56 & 0.50 & 41 & & & & & & & & & & \\
\hline 2. AFIT & 60.80 & 29.11 & 41 & $0.80 * *$ & & & & & & & & & \\
\hline 3. $\mathrm{REF}$ & 41.90 & 31.66 & 41 & $0.28 *$ & $0.30 *$ & & & & & & & & \\
\hline 4. Age in years & 45.03 & 10.81 & 34 & 0.02 & 0.09 & $-0.33 *$ & & & & & & & \\
\hline $\begin{array}{l}5 . \text { Work experience in } \\
\text { years }\end{array}$ & 23.21 & 10.22 & 41 & 0.21 & 0.16 & -0.19 & $0.92 * *$ & & & & & & \\
\hline $\begin{array}{l}\text { 6. Familiarity with duties } \\
\text { of accounting managers }\end{array}$ & 7.47 & 1.89 & 40 & -0.25 & $-0.27 *$ & 0.00 & 0.09 & 0.17 & & & & & \\
\hline $\begin{array}{l}\text { 7. Number of executive } \\
\text { searches completed }\end{array}$ & 518.99 & $1,167.28$ & 40 & -0.12 & $-0.28 *$ & -0.17 & $0.34 *$ & $0.35 *$ & 0.24 & & & & \\
\hline $\begin{array}{l}\text { 8. Number of } \\
\text { accounting/finance } \\
\text { searches }\end{array}$ & 400.57 & 636.93 & 41 & -0.25 & $-0.38 * *$ & -0.07 & 0.10 & 0.16 & $0.34 *$ & $0.74 * *$ & & & \\
\hline $\begin{array}{l}\text { 9. Number of accounting } \\
\text { courses taken }\end{array}$ & 5.91 & 5.55 & 40 & -0.09 & -0.02 & -0.08 & 0.23 & $0.40 * *$ & $0.47 * *$ & 0.18 & $0.30 *$ & & \\
\hline $\begin{array}{l}\text { 10. Number of finance } \\
\text { courses taken }\end{array}$ & 4.13 & 3.75 & 39 & $-0.37 *$ & $-0.33 *$ & -0.17 & -0.02 & 0.13 & $0.48 * *$ & -0.04 & 0.07 & $0.54 * *$ & \\
\hline 11. Percent male & 63.89 & 48.71 & 40 & -0.06 & -0.08 & -0.05 & $0.49 * *$ & $0.43 * *$ & $0.45 * *$ & 0.24 & 0.24 & 0.20 & 0.18 \\
\hline
\end{tabular}


Panel B: Regression Results $(n=41)$

\begin{tabular}{|c|c|c|c|c|c|}
\hline \multirow{2}{*}{$\begin{array}{c}\text { Dependent } \\
\text { Variable }\end{array}$} & \multicolumn{2}{|c|}{ Independent Variable } & & \multirow{2}{*}{$\begin{array}{c}\text { Model } \\
\text { F-statistic }\end{array}$} & \multirow{2}{*}{$\begin{array}{c}\text { Adjusted } \\
\mathbf{R}^{2}(\%) \\
\end{array}$} \\
\hline & Intercept & CAND & & & \\
\hline REF & 31.89 & $\beta_{4}=17.85$ & & 3.40 & 5.67 \\
\hline t-statistic & 4.40 & 1.84 & $*$ & & \\
\hline AFIT & 34.71 & $\beta_{5}=46.51$ & & 70.78 & 63.56 \\
\hline t-statistic & 8.38 & 8.41 & ** & & \\
\hline
\end{tabular}

See Section 6 for a discussion of Experiment 3. CAND is the job candidate profile manipulated between subjects as Candidate A (coded as 1) or Candidate B (coded as 0); AFIT is participants' mean response to the five accounting fit questions shown in Appendix D (responses are provided on a 100-point sliding scale, with the left endpoint labeled "Definitely not" and the right endpoint labeled "Definitely yes"); REF is participants' response to the client referral question, which states "Based on your evaluation of the candidate and the information about the client, how likely is the consultant to refer the candidate to the client to interview for the senior accounting manager position?" (participants respond on a 100-point sliding scale, with the left endpoint labeled "Definitely not" and the right endpoint labeled "Definitely yes"). Some participants did not answer all demographic questions, so the number of observations for each demographic question varies. Responses to the question about familiarity with the duties of accounting managers are provided on a 10-point scale with higher responses indicating greater familiarity. ** and * denote statistical significance at $\mathrm{p}<0.01$ and $\mathrm{p}<0.05$, respectively. P-values are one-tailed where we have directional predictions. 